Keywords: SCIX, MST, $m M S T$, CST, desorption

Retention: Permanent

\title{
Desorption of Sorbates from MST, mMST, and CST Under Various Conditions
}

K. M. L. Taylor-Pashow

D. T. Hobbs

June 2011

Savannah River National Laboratory Savannah River Nuclear Solutions, LLC Aiken, SC 29808

Prepared for the U.S. Department of Energy under contract number DE-AC09-08SR22470.

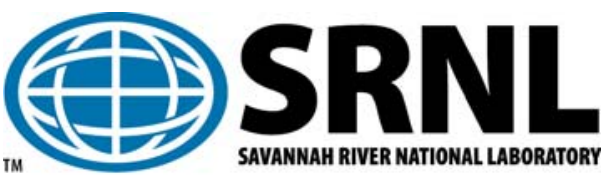


SRNL-STI-2011-00340

Revision 0

\section{DISCLAIMER}

This work was prepared under an agreement with and funded by the U.S. Government. Neither the U.S. Government or its employees, nor any of its contractors, subcontractors or their employees, makes any express or implied:

1. warranty or assumes any legal liability for the accuracy, completeness, or for the use or results of such use of any information, product, or process disclosed; or

2. representation that such use or results of such use would not infringe privately owned rights; or

3. endorsement or recommendation of any specifically identified commercial product, process, or service.

Any views and opinions of authors expressed in this work do not necessarily state or reflect those of the United States Government, or its contractors, or subcontractors.

\section{Printed in the United States of America \\ Prepared for \\ U.S. Department of Energy}




\section{REVIEWS AND APPROVALS}

AUTHORS:

K. M. L. Taylor-Pashow, Separations and Actinide Science Programs

Date

D. T. Hobbs, Separations and Actinide Science Programs

Date

TECHNICAL REVIEW:

T. B. Peters, Separations and Actinide Science Programs

Date

APPROVAL:

S. D. Fink, Manager

Date

Separations and Actinide Science Programs

F. M. Pennebaker, Manager

Date

Advanced Characterization and Processing

S. L. Marra, Manager

Date

Environmental \& Chemical Process Technology Research Programs

T. H. Huff, Manager

Date

Small Column Ion Exchange Engineering 


\section{EXECUTIVE SUMMARY}

A series of experiments were performed to examine desorption from monosodium titanate (MST), modified monosodium titanate (mMST), and crystalline silicotitanate (CST) under various conditions. The first two experiments examined desorption from MST and CST under two different sludge treatment processes, aluminum dissolution and sludge washing. Desorption of all sorbates was observed to varying degrees under the aluminum dissolution conditions. The extent of desorption ranged from $<3 \%$ to about $50 \%$ after 4 weeks, with $\mathrm{Pu}$ exhibiting the lowest desorption. At the end of the experiment, the temperature was reduced from $65{ }^{\circ} \mathrm{C}$ to $25{ }^{\circ} \mathrm{C}$ and the tests monitored for an additional two weeks. After reducing the temperature, partial resorption of the sorbates was observed with both MST and CST. Under the sludge washing conditions, no desorption of sorbates was observed with MST; however, some additional sorption did occur. For CST, a small amount of Cs leached from the material during the first day of testing, but no further leaching was observed over the remaining test period.

The final test was designed to examine the possibility of desorption from both MST and mMST upon increasing the solid to liquid phase ratio. The results of these tests indicated some desorption of $\mathrm{Pu}$ from MST within the first two weeks after changing the phase ratio, then resorption of some of the leached $\mathrm{Pu}$ over the remaining 4 weeks of the experiment. No desorption of any sorbates was observed for mMST under these conditions. 


\section{TABLE OF CONTENTS}

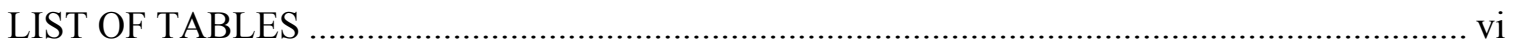

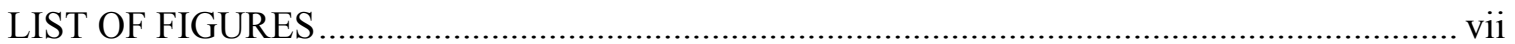

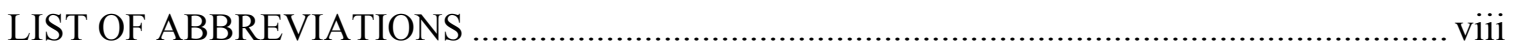

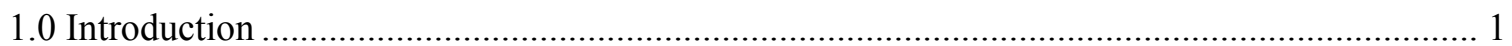

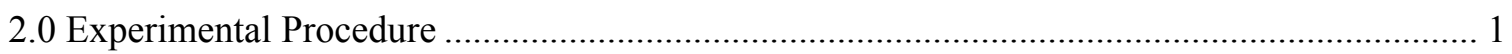

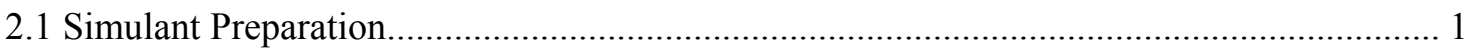

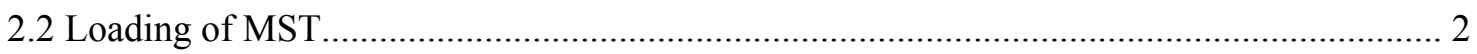

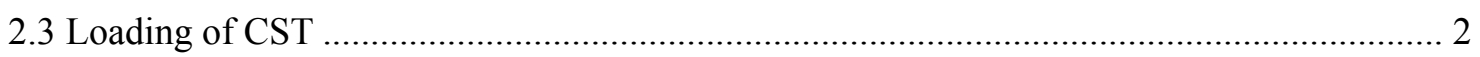

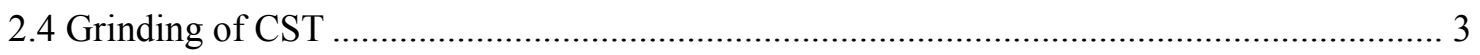

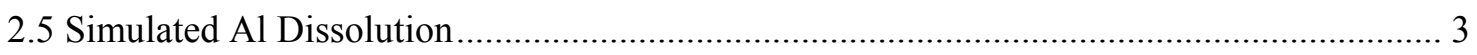

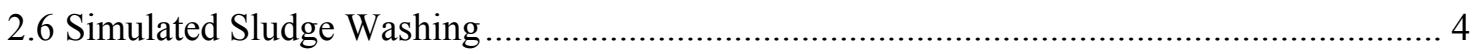

2.7 Desorption Under Changing Phase Ratio Conditions.................................................... 5

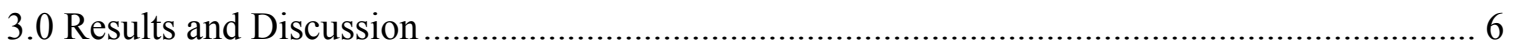

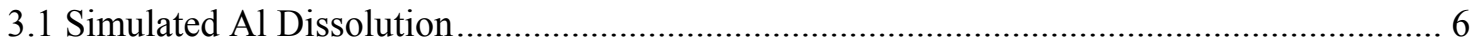

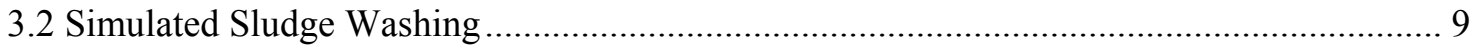

3.3 Desorption Under Changing Phase Ratio Conditions.................................................... 13

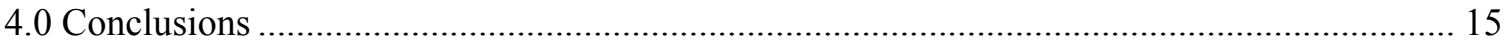

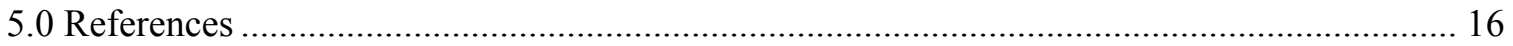

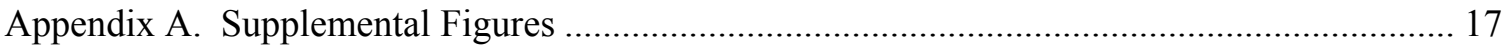




\section{LIST OF TABLES}

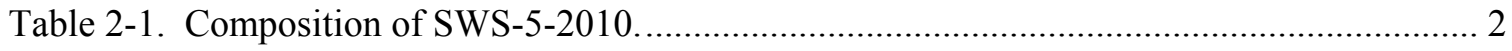

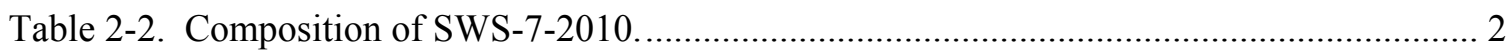

Table 2-3. Composition of DSS and MST-Al Dissolution Simulant. .......................................... 4

Table 2-4. Composition of DSS and CST-Al Dissolution Simulant. ............................................ 4

Table 2-5. Composition of Sludge Washing Simulants for MST.................................................. 5

Table 2-6. Composition of Sludge Washing Simulants for CST. ............................................... 5 


\section{LIST OF FIGURES}

Figure 1. Percentage of ${ }^{85} \mathrm{Sr}$ leached from MST under simulated $\mathrm{Al}$ dissolution conditions (open data points indicate values that were below the quantifiable limit).....

Figure 2. Percentage of ${ }^{238} \mathrm{U}$ leached from MST under simulated Al dissolution conditions. ....... 7

Figure 3. Percentage of ${ }^{237} \mathrm{~Np}$ leached from MST under simulated Al dissolution conditions. ..... 8

Figure 4. Percentage of $\mathrm{Pu}$ leached from MST under simulated Al dissolution conditions........... 8

Figure 5. Percentage of Cs leached from CST under simulated Al dissolution conditions............ 9

Figure $6 .{ }^{238} \mathrm{U}$ concentration vs. contact time under simulated sludge washing conditions......... 10

Figure $7 .{ }^{237} \mathrm{~Np}$ concentration vs. contact time under simulated sludge washing conditions (open data points indicate value that were below the quantifiable limit) ........................................ 10

Figure 8. Pu concentration vs. contact time under simulated sludge washing conditions (open data points indicate value that were below the quantifiable limit)...................................... 11

Figure 9. Cs concentration vs. contact time under simulated sludge washing conditions............ 12

Figure 10. Percentage of Cs leached from CST under simulated sludge washing conditions (the 2 $\mathrm{M} \mathrm{Na}$ control data points are in the same positions as the $0.5 \mathrm{M} \mathrm{Na}$ control data points, therefore they are hidden in this plot).

Figure 11. ${ }^{238} \mathrm{U}$ concentration vs. time after increasing the solid to liquid phase ratio................. 14

Figure 12. ${ }^{237} \mathrm{~Np}$ concentration vs. time after increasing the solid to liquid phase ratio............... 14

Figure 13. Pu concentration vs. time after increasing the solid to liquid phase ratio.................. 15

Figure A-1. Activity of ${ }^{85} \mathrm{Sr}$ leached from MST vs. time under simulated Al dissolution conditions (open data points indicate values that were below the quantifiable limit)........... 18

Figure A-2. Concentration of $\mathrm{U}$ leached from MST vs. time under simulated Al dissolution conditions.

Figure A-3. Concentration of ${ }^{237} \mathrm{~Np}$ leached from MST vs. time under simulated Al dissolution conditions (open data points indicate values that were below the quantifiable limit).

Figure A-4. Concentration of $\mathrm{Pu}$ leached from MST vs. time under simulated Al dissolution conditions.

Figure A-5. Concentration of Cs leached from CST vs. time under simulated Al dissolution conditions. 


\section{LIST OF ABBREVIATIONS}

$\begin{array}{ll}\text { CST } & \text { crystalline silicotitanate } \\ \text { DSS } & \text { decontaminated salt solution } \\ \text { DWPF } & \text { Defense Waste Processing Facility } \\ \text { ICP-MS } & \text { inductively coupled plasma - mass spectroscopy } \\ \text { MSP } & \text { Modular Salt Processing } \\ \text { MST } & \text { monosodium titanate } \\ \text { mMST } & \text { modified monosodium titanate } \\ \text { PuTTA } & \text { plutonium thenoyltrifluoroacetone scintillation } \\ \text { SCIX } & \text { small column ion exchange } \\ \text { SRR } & \text { Savannah River Remediation } \\ \text { TTQAP } & \text { Task Technical and Quality Assurance Plan }\end{array}$




\subsection{Introduction}

The Small Column Ion Exchange (SCIX) Program (formerly referred to as the Modular Salt Processing (MSP) Project) seeks to deploy equipment to remove the ${ }^{134,137} \mathrm{Cs},{ }^{90} \mathrm{Sr}$, and alphaemitting radionuclides (principally ${ }^{238,239,240} \mathrm{Pu}$ and ${ }^{237} \mathrm{~Np}$ ) from the high level waste salt solutions. The equipment is installed within a high level waste tank to take advantage of the shielding provided by the waste tank. The process will involve adding monosodium titanate (MST) to the waste tank (i.e., Tank $41 \mathrm{H}$ ) to sorb the $\mathrm{Sr}$ and select actinides, removing the MST and entrained sludge with in-riser rotary microfilters, and subsequently using ion-exchange columns containing crystalline silicotitanate (CST) to remove the Cs. After being loaded with Cs, the CST will be ground to reduce the particle size and then transferred into another waste tank (e.g., Tank 40H). The MST and sludge solids stream will be transported to a sludge batch preparation tank (i.e., Tank $42 \mathrm{H}$ or Tank $51 \mathrm{H}$ ) once the SCIX batch is processed. Both streams, MST/solids and CST, will ultimately be transported into and vitrified inside the Defense Waste Processing Facility (DWPF).

Before reaching DWPF, the loaded MST and CST solids may be exposed to some of the sludge treatment processes, including sludge washing and aluminum dissolution. The CST will only be exposed to these treatment processes if it is transferred with the MST to Tank $42 \mathrm{H}$ or $51 \mathrm{H}$, which is not the current baseline. The baseline process will transfer the CST to Tank $40 \mathrm{H}$, where it will be combined with sludge that has already been through the $\mathrm{Al}$ dissolution and washing sequences. Bench scale tests were performed to determine the effect of sludge washing and aluminum dissolution on the desorption of sorbates from MST and CST. In addition, results from the prior $\mathrm{Sr}$ and actinide sorption testing indicated the possible desorption of sorbates from MST and modified MST (mMST) under changing phase ratio conditions. ${ }^{1}$ A similar change in phase ratio is expected to occur during SCIX processing as treated supernate is pumped from the tank leaving a heel with increasing MST concentration. Experiments were performed to confirm this observation.

This work was performed at the request of the SCIX Engineering group of Savannah River Remediation $(\mathrm{SRR})^{2}$ and was controlled by a Task Technical and Quality Assurance Plan (TTQAP) ${ }^{3}$

\subsection{Experimental Procedure}

\subsection{Simulant Preparation}

The simulant used in the MST and mMST testing was the same simulant used for the $\mathrm{Sr}$ and actinide sorption studies. ${ }^{1}$ The composition of this simulant, SWS-5-2010, is provided in Table 2-1. For the CST experiments, a non-rad simulant was prepared having a similar chemical composition to SWS-5-2010, with the exception of the radioactive components. The composition of this simulant, SWS-7-2010, is provided in Table 2-2. 
Table 2-1. Composition of SWS-5-2010.

\begin{tabular}{|c|c|c|}
\hline Component & Target Concentration & Measured Concentration \\
\hline $\mathrm{NaNO}_{3}$ & $2.03 \mathrm{M}$ & $1.81 \pm 0.18 \mathrm{M}$ \\
\hline $\mathrm{NaOH}$ & $2.21 \mathrm{M}$ & $2.00 \pm 0.20 \mathrm{M}$ \\
\hline $\mathrm{Na}_{2} \mathrm{SO}_{4}$ & $0.14 \mathrm{M}$ & $0.11 \pm 0.011 \mathrm{M}$ \\
\hline $\mathrm{NaAl}(\mathrm{OH})_{4}$ & $0.28 \mathrm{M}$ & $0.305 \pm 0.031 \mathrm{M}$ \\
\hline $\mathrm{NaNO}_{2}$ & $0.50 \mathrm{M}$ & $0.519 \pm 0.052 \mathrm{M}$ \\
\hline $\mathrm{NaCO}_{3}$ & $0.15 \mathrm{M}$ & $0.157 \pm 0.016$ \\
\hline Total Na & $5.6 \mathrm{M}$ & $5.83 \pm 0.58 \mathrm{M}$ \\
\hline Total Sr & $6.0 \mathrm{mg} / \mathrm{L}$ & $0.860 \pm 0.172 \mathrm{mg} / \mathrm{L}$ \\
\hline${ }^{85} \mathrm{Sr}$ & $\geq 10,000 \mathrm{dpm} / \mathrm{mL}$ & $10,300 \pm 130 \mathrm{dpm} / \mathrm{mL}$ \\
\hline Total Pu & $0.2 \mathrm{mg} / \mathrm{L}$ & $0.177 \pm 0.018 \mathrm{mg} / \mathrm{L}$ \\
\hline${ }^{237} \mathrm{~Np}$ & $0.5 \mathrm{mg} / \mathrm{L}$ & $0.456 \pm 0.091 \mathrm{mg} / \mathrm{L}$ \\
\hline Total U & $10 \mathrm{mg} / \mathrm{L}$ & $9.84 \pm 1.97 \mathrm{mg} / \mathrm{L}$ \\
\hline${ }^{137} \mathrm{Cs}$ & $\geq 30,000 \mathrm{dpm} / \mathrm{mL}$ & $112,000 \pm 5600 \mathrm{dpm} / \mathrm{mL}$ \\
\hline
\end{tabular}

Table 2-2. Composition of SWS-7-2010.

\begin{tabular}{||c|c|c||}
\hline Component & Target Concentration & Measured Concentration \\
\hline $\mathbf{N a N O}_{3}$ & $2.03 \mathrm{M}$ & $2.05 \pm 0.21 \mathrm{M}$ \\
\hline $\mathrm{NaOH}$ & $2.21 \mathrm{M}$ & $1.92 \pm 0.19 \mathrm{M}$ \\
\hline $\mathrm{Na}_{2} \mathrm{SO}_{4}$ & $0.14 \mathrm{M}$ & $0.13 \pm 0.013 \mathrm{M}$ \\
\hline $\mathrm{NaAl}_{4}(\mathbf{O H})_{4}$ & $0.28 \mathrm{M}$ & $0.274 \pm 0.027 \mathrm{M}$ \\
\hline $\mathrm{NaNO}_{2}$ & $0.50 \mathrm{M}$ & $0.517 \pm 0.052 \mathrm{M}$ \\
\hline $\mathbf{N a C O}_{3}$ & $0.15 \mathrm{M}$ & $0.143 \pm 0.014$ \\
\hline Total $\mathbf{N a}$ & $5.6 \mathrm{M}$ & $5.35 \pm 0.54 \mathrm{M}$ \\
\hline Total Sr & $6.0 \mathrm{mg} / \mathrm{L}$ & $0.796 \pm 0.159 \mathrm{mg} / \mathrm{L}$ \\
\hline Total Cs & $18.6 \mathrm{mg} / \mathrm{L}$ & $22.0 \pm 4.40 \mathrm{mg} / \mathrm{L}$ \\
\hline
\end{tabular}

\subsection{Loading of MST}

A sample of MST was loaded with sorbates by contacting it with SWS-5-2010 for a period of two weeks. Specifically, $5.48 \mathrm{~g}$ of a $14.60 \mathrm{wt} \%$ suspension of MST (Optima, Lot \# 00-QAB-417) was added to $2 \mathrm{~L}$ of SWS-5-2010, giving a final MST concentration of $0.4 \mathrm{~g} / \mathrm{L}$, nominal conditions for the process. The mixture was stirred at ambient temperature for two weeks. The loaded solids $(0.8 \mathrm{~g})$ were then collected by filtering though a $0.45-\mu \mathrm{m}$ disposable filter. The solids were transferred from the filter using a small amount of the filtrate, and were diluted to a total volume of $10 \mathrm{~mL}$ with additional filtrate, giving an MST suspension with a final concentration of $0.08 \mathrm{~g} / \mathrm{mL}$, assuming no loss of the solids. Samples of the filtrate were analyzed for sorbate concentrations to determine the extent of loading. The decontaminated salt solution (DSS) was then adjusted for either the aluminum dissolution or sludge washing experiments as described below.

\subsection{Loading of CST}

A sample of dry, unground CST was placed in a fine (70 mesh, or 210 microns) sieve to remove any fines present. No solids were observed to pass through the sieve. $3.05 \mathrm{~g}$ of the CST were then transferred into a small column. The internal diameter of the column was $1.44 \mathrm{~cm}$, and the bed height was $1.84 \mathrm{~cm}$. Distilled water was then added to the CST in the column. When the bed was agitated with the distilled water, the water above the bed became slightly cloudy indicating the presence of fines. This water was removed using a pipette, and the bed was rinsed several more times with distilled water to remove the fines. A solution of $2 \mathrm{M}$ sodium hydroxide was 
then pumped through the column at a rate of $3.04 \mathrm{~mL} / \mathrm{min}$ for 1 hour. The pump was then stopped, and the CST was left to soak in the $2 \mathrm{M} \mathrm{NaOH}$, overnight. The temperature of the column was controlled throughout the experiment using a temperature controlled water bath set to $25^{\circ} \mathrm{C}$. The water from the water bath was recirculated through the jacketing on the column. The following day, $2 \mathrm{M}$ sodium hydroxide was pumped through the column at a rate of $3.04 \mathrm{~mL} / \mathrm{min}$ for 1 hour. The feed was then switched from the $2 \mathrm{M} \mathrm{NaOH}$ to the simulant feed (SWS-7-2010), and the flow rate was decreased to approximately $0.21 \mathrm{~mL} / \mathrm{min}$. Collection of the effluent began 2 hours after switching to the simulant feed, allowing enough time for the $2 \mathrm{M} \mathrm{NaOH}$ to be replaced by the simulant. A total of approximately $1.85 \mathrm{~L}$ of simulant was processed through the column. At the conclusion of the experiment, the pump was stopped, and a slurry pipette was used to transfer the CST from the column to a vial, using the solution above the bed to suspend and transfer all of the beads. The CST was then isolated by filtering, and was briefly dried in air by leaving the solid on the filter (with vacuum) for 1 hour. The solids were then transferred to a small vial, and were further dried over desiccant for 4 days.

\subsection{Grinding of CST}

Before use in the desorption tests, the loaded CST was further dried in an $80{ }^{\circ} \mathrm{C}$ oven for 1 hour. The CST was then ground using a mortar and pestle. The ground CST was passed though a series of sieves, sizes 200, 270, and 400 (or 74, 53, and 37 microns, respectively). CST passing all the way through the number 400 sieve will be less than or equal to $37 \mu \mathrm{m}$ in size. For the $\mathrm{Al}$ dissolution experiments, after grinding and sieving, $1.42047 \mathrm{~g}$ of CST was obtained that was $\leq 37 \mu \mathrm{m}$ in size. This was then combined with $0.10500 \mathrm{~g}$ of CST that was ground to a size between 37 and $53 \mu \mathrm{m}$ (passed through the 200 and 270 sieves, but not the 400 sieve). The final particle size distribution was $93.12 \mathrm{wt} \% \leq 37 \mu \mathrm{m}$, and $6.88 \mathrm{wt} \%$ less than $53 \mu \mathrm{m}$ but greater than $37 \mu \mathrm{m}$. For the sludge washing experiments, $0.63817 \mathrm{~g}$ of CST $\leq 37 \mu \mathrm{m}$ was combined with $0.05006 \mathrm{~g}$ of CST with a particles size distribution of $93.12 \mathrm{wt} \% \leq 37 \mu \mathrm{m}$ and $6.88 \mathrm{wt} \%$ between 37 and $53 \mu \mathrm{m}$ (remaining ground CST not used in the Al dissolution experiment), and with $0.04788 \mathrm{~g}$ of CST between 37 and $53 \mu \mathrm{m}$. Therefore, the final particle size distribution of the ground CST used for the sludge washing experiments was $93.05 \mathrm{wt} \% \leq 37 \mu \mathrm{m}$ and $6.95 \mathrm{wt} \%$ less than $53 \mu \mathrm{m}$ but greater than $37 \mu \mathrm{m}$.

\subsection{Simulated Al Dissolution}

The DSS from the MST loading experiments was used to prepare the Al dissolution simulant with the addition of sodium hydroxide and aluminum nitrate to adjust the free hydroxide and $\mathrm{Al}$ concentrations of the solution to those expected at the end of an $\mathrm{Al}$ dissolution cycle, i.e. $5.21 \mathrm{M}$ $\mathrm{OH}^{-}$and $1.13 \mathrm{M} \mathrm{Al}^{4}$ Samples of the Al dissolution simulant were taken and submitted for analysis to determine the actual hydroxide and Al concentrations, along with the sorbate concentrations. The results are given in Table 2-3. For the experiments, $200 \mathrm{~mL}$ of the $\mathrm{Al}$ dissolution simulant was added to a $250-\mathrm{mL}$ bottle. An aliquot $(1.75 \mathrm{~mL})$ of the $0.08 \mathrm{~g} / \mathrm{mL}$ suspension of MST was then added to the bottle, giving a final MST concentration of $\sim 0.7 \mathrm{~g} / \mathrm{L}$. The MST concentration was based on the addition of MST from one complete SCIX batch (treatment of 1,000,000 gallons) to the total volume in Tank $51 \mathrm{H}$ during $\mathrm{Al}$ dissolution. ${ }^{4}$ The bottle was then briefly mixed by shaking, and 0 -hour samples removed. The test was performed in duplicate. The bottles were transferred to a $65^{\circ} \mathrm{C}$ shaker oven, and were shaken at a speed of $175 \mathrm{rpm}$. Samples were then removed, at temperature, at the following times: 6, 12, 24, 48, 96 hours, and 1,2,3, and 4 weeks. The samples were removed and filtered through a $0.1-\mu \mathrm{m}$ filter, and an aliquot of the filtrate was then acidified with an equal volume of $10 \mathrm{M} \mathrm{HNO}_{3}$. The acidified samples were submitted for inductively coupled plasma - mass spectroscopy (ICP-MS), gamma scan, and plutonium thenoyltrifluoroacetone scintillation (PuTTA) analyses. Early results 
indicated desorption of sorbates, so the tests were continued for an additional two weeks, reducing the temperature to $25{ }^{\circ} \mathrm{C}$ to determine if resorption of the sorbates occurred.

A similar experiment was performed using the loaded, ground CST. For these experiments, the column effluent was used to prepare the Al dissolution simulant with the addition of sodium hydroxide and aluminum nitrate to adjust the free hydroxide and $\mathrm{Al}$ concentrations to those expected at the end of an $\mathrm{Al}$ dissolution cycle. The compositions are given in Table 2-4. For the experiments, $200 \mathrm{~mL}$ of the Al dissolution simulant was added to a $250-\mathrm{mL}$ bottle followed by $0.732 \mathrm{~g}$ of loaded, ground CST, giving a final CST concentration of $3.66 \mathrm{~g} / \mathrm{L}$. The CST concentration was based on the addition of CST from one complete SCIX batch (treatment of $1,000,000$ gallons) to the total volume in Tank $51 \mathrm{H}$ during $\mathrm{Al}$ dissolution. ${ }^{4}$ The test was performed in duplicate. The remaining details are identical to the MST experiment, with the exception that samples were only submitted for ICP-MS analysis.

Table 2-3. Composition of DSS and MST-Al Dissolution Simulant.

\begin{tabular}{||c|c|c||}
\hline \hline Component & DSS & MST-Al Dissolution Simulant \\
\hline NaOH & $1.98 \mathrm{M} \pm 0.198 \mathrm{M}$ & $2.98 \pm 0.298 \mathrm{M}$ \\
\hline $\mathbf{N a A l}(\mathbf{O H})_{4}$ & $0.284 \mathrm{M} \pm 0.028 \mathrm{M}$ & $0.749 \pm 0.075 \mathrm{M}$ \\
\hline Total Na & $5.39 \pm 0.54 \mathrm{M}$ & $7.53 \pm 0.75 \mathrm{M}$ \\
\hline Total Sr & $0.149 \pm 0.0298 \mathrm{mg} / \mathrm{L}$ & $<0.0969 \mathrm{mg} / \mathrm{L}$ \\
\hline${ }^{\mathbf{8 5}} \mathbf{S r}$ & $<252 \mathrm{dpm} / \mathrm{mL}$ & $<245 \mathrm{dpm} / \mathrm{mL}$ \\
\hline Total Pu & $4.40 \pm 0.33 \mu \mathrm{g} / \mathrm{L}$ & $1.54 \pm 0.14 \mu \mathrm{g} / \mathrm{L}$ \\
\hline${ }^{\mathbf{2 3 7}} \mathbf{N p}$ & $0.157 \pm 0.031 \mathrm{mg} / \mathrm{L}$ & $0.162 \pm 0.032 \mathrm{mg} / \mathrm{L}$ \\
\hline Total U & $7.04 \pm 1.41 \mathrm{mg} / \mathrm{L}$ & $4.52 \pm 0.90 \mathrm{mg} / \mathrm{L}$ \\
\hline${ }^{\mathbf{1 3 7}} \mathbf{C s}$ & $110,000 \pm 5,500 \mathrm{dpm} / \mathrm{mL}$ & $70,800 \pm 3,540 \mathrm{dpm} / \mathrm{mL}$ \\
\hline
\end{tabular}

Table 2-4. Composition of DSS and CST-Al Dissolution Simulant.

\begin{tabular}{||c|c|c||}
\hline Component & DSS & CST-Al Dissolution Simulant \\
\hline $\mathbf{N a O H}$ & $1.98 \mathrm{M} \pm 0.198 \mathrm{M}$ & $3.07 \pm 0.307 \mathrm{M}$ \\
\hline $\mathrm{NaAl}(\mathbf{O H})_{4}$ & $0.277 \mathrm{M} \pm 0.028 \mathrm{M}$ & $0.682 \pm 0.068 \mathrm{M}$ \\
\hline Total Na & $5.61 \pm 0.56 \mathrm{M}$ & $7.74 \pm 0.77 \mathrm{M}$ \\
\hline Total Sr & $<0.030 \mathrm{mg} / \mathrm{L}$ & $0.0656 \pm 0.0131 \mathrm{mg} / \mathrm{L}$ \\
\hline Total Cs & $0.476 \pm 0.095 \mathrm{mg} / \mathrm{L}$ & $0.336 \pm 0.067 \mathrm{mg} / \mathrm{L}$ \\
\hline
\end{tabular}

\subsection{Simulated Sludge Washing}

The DSS from the MST loading experiments was used to prepare the sludge washing simulant by diluting with distilled water. The DSS was diluted by factors of 2.7 and 10.8 to achieve $\mathrm{Na}$ concentrations expected at an intermediate and the final stages of washing, i.e. $2 \mathrm{M}$ and $0.5 \mathrm{M} \mathrm{Na}$. Samples of each sludge-washing simulant were taken and submitted for analysis to determine the actual $\mathrm{Na}$ and sorbate concentrations. The results are given in Table 2-5. For the experiments, $100 \mathrm{~mL}$ of each simulant was added to two $100-\mathrm{mL}$ bottles. Aliquots $(0.85 \mathrm{~mL})$ of the $0.08 \mathrm{~g} / \mathrm{mL}$ suspension of MST were then added to each bottle, giving final MST concentrations of $0.68 \mathrm{~g} / \mathrm{L}$. The MST concentration was based on the addition of MST from one complete SCIX batch (treatment of 1,000,000 gallons) to the average volume in Tank 51H during sludge washing. ${ }^{5}$ The bottles were then briefly mixed by shaking, and 0-hour samples were removed. The bottles were transferred to a $25{ }^{\circ} \mathrm{C}$ shaker oven, and were shaken at a speed of $175 \mathrm{rpm}$. Samples were removed at the following times: 1, 4, 8, 14, 22, 28, 37, and 43 days. The samples were removed and filtered through a $0.1-\mu \mathrm{m}$ filter, and an aliquot of the filtrate was acidified with an equal volume of $5 \mathrm{M} \mathrm{HNO}_{3}$. The acidified samples were submitted for ICP-MS, gamma scan, and PuTTA analyses. Samples from the 22, 28, and 37-day events were not analyzed since the results from 43 days did not show significant change from the results at 14 days. 
A similar experiment was performed using the loaded, ground CST. For these experiments, the column effluent was used to prepare the sludge washing simulants by diluting with distilled water. The column effluent was diluted by factors of 2.8 and 11.2 to achieve $\mathrm{Na}$ concentrations expected at an intermediate and the final stages of washing, i.e. $2 \mathrm{M}$ and $0.5 \mathrm{M} \mathrm{Na}$. The compositions are given in Table 2-6. For the experiments, $100 \mathrm{~mL}$ of each simulant was added to two $100-\mathrm{mL}$ bottles, followed by $0.358 \mathrm{~g}$ of loaded, ground CST, giving a final CST concentration of $3.58 \mathrm{~g} / \mathrm{L}$. The CST concentration was based on the addition of CST from one complete SCIX batch (treatment of 1,000,000 gallons) to the average volume in Tank $51 \mathrm{H}$ during sludge washing. ${ }^{5}$ The remaining details are identical to the MST experiment, with the exception that samples were only submitted for ICP-MS analysis.

Table 2-5. Composition of Sludge Washing Simulants for MST.

\begin{tabular}{||c|c|c||}
\hline \hline Component & $\begin{array}{c}\text { 2 M Na - Sludge } \\
\text { Washing Simulant - MST }\end{array}$ & $\begin{array}{c}\text { 0.5 M Na - Sludge Washing } \\
\text { Simulant - MST }\end{array}$ \\
\hline Total Na $^{\mathbf{a}}$ & $0.974 \pm 0.097 \mathrm{M}$ & $0.290 \pm 0.030 \mathrm{M}$ \\
\hline $\mathbf{N a A l}(\mathbf{O H})_{4}{ }^{\mathbf{a}}$ & $0.050 \mathrm{M} \pm 0.005 \mathrm{M}$ & $0.015 \pm 0.001 \mathrm{M}$ \\
\hline Total Sr & $<0.00908 \mathrm{mg} / \mathrm{L}$ & $<0.00908 \mathrm{mg} / \mathrm{L}$ \\
\hline${ }^{85} \mathbf{S r}$ & $<525 \mathrm{dpm} / \mathrm{mL}$ & $<303 \mathrm{dpm} / \mathrm{mL}$ \\
\hline Total Pu & $2.59 \pm 0.17 \mu \mathrm{g} / \mathrm{L}$ & $0.313 \pm 0.053 \mu \mathrm{g} / \mathrm{L}$ \\
\hline${ }^{237} \mathbf{N p}$ & $54.8 \pm 11.0 \mu \mathrm{g} / \mathrm{L}$ & $15.4 \pm 3.1 \mu \mathrm{g} / \mathrm{L}$ \\
\hline Total U & $2.53 \pm 0.51 \mathrm{mg} / \mathrm{L}$ & $0.716 \pm 0.143 \mathrm{mg} / \mathrm{L}$ \\
\hline${ }^{\mathbf{1 3 7}} \mathbf{C s}$ & $77,400 \pm 3,870 \mathrm{dpm} / \mathrm{mL}$ & $24,000 \pm 1,200 \mathrm{dpm} / \mathrm{mL}$ \\
\hline \hline
\end{tabular}

a) ICP-ES results appeared to be a factor of 2 below what was expected. ICP-MS results were consistent with the dilution factors used, indicating no error was made in performing the dilutions.

Table 2-6. Composition of Sludge Washing Simulants for CST.

\begin{tabular}{|c|c|c||}
\hline Component & $\begin{array}{c}\text { 2 M Na - Sludge } \\
\text { Washing Simulant - CST }\end{array}$ & $\begin{array}{c}\text { 0.5 M Na - Sludge Washing } \\
\text { Simulant - CST }\end{array}$ \\
\hline Total Na & $1.90 \pm 0.19 \mathrm{M}$ & $0.461 \pm 0.046 \mathrm{M}$ \\
\hline NaAl(OH) $)_{4}$ & $0.094 \mathrm{M} \pm 0.009 \mathrm{M}$ & $0.022 \pm 0.002 \mathrm{M}$ \\
\hline Total Sr & $5.71 \pm 1.14 \mu \mathrm{g} / \mathrm{L}$ & $7.02 \pm 1.40 \mu \mathrm{g} / \mathrm{L}$ \\
\hline Total Cs & $170 \pm 34 \mu \mathrm{g} / \mathrm{L}$ & $43.6 \pm 8.7 \mu \mathrm{g} / \mathrm{L}$ \\
\hline
\end{tabular}

\subsection{Desorption Under Changing Phase Ratio Conditions}

To confirm the prior observation from the $\mathrm{Sr}$ and actinide sorption testing, that increasing the solid to liquid phase ratio after sorption has occurred (such as by filtration) may cause desorption of sorbates, experiments were performed using the solids and decontaminated solutions remaining from the $\mathrm{Sr}$ and actinide sorption control tests. ${ }^{1}$ These samples consisted of MST and mMST, which had been contacted with a radioactive simulated salt solution, SWS-5-2010, for 20 weeks. The $\mathrm{Sr}$ and actinide sorption test occurred during the first six weeks of this time period, during which the bottles were being shaken in a waterbath shaker. Samples had also been removed periodically. Prior to removing each sample, the bottles were vigorously shaken to homogenously suspend the solids. This ensures that the solids concentrations remain close to $0.4 \mathrm{~g} / \mathrm{L}$ and $0.2 \mathrm{~g} / \mathrm{L}$, for MST and mMST, respectively. For the remaining 14 weeks, the bottles stood undisturbed at ambient laboratory temperatures.

For this desorption experiment, the volume of solution remaining in each bottle was estimated to be approximately $120 \mathrm{~mL}$. Approximately one-half $(60 \mathrm{~mL})$ of the supernate was carefully removed using a pipette while taking care not to disturb the settled solids. After removing the 60 $\mathrm{mL}$ of supernate, the volume remaining was measured by transferring to a graduated cylinder. 
The reduced volumes of slurry were then returned to the bottle, and were stirred at room temperature for 6 weeks. Samples of the removed supernate were submitted for analysis to determine the starting concentrations of sorbates. Samples were removed from the experiments every 2 weeks, for a total of six weeks. At each sampling event, the mixture was shaken to ensure the solids were homogeneously suspended. A sample was then removed and filtered through a $0.1-\mu \mathrm{m}$ syringe filter. A sample of the filtrate was acidified with an equal volume of 5 $\mathrm{MHNO}_{3}$. The acidified samples were submitted for ICP-MS, gamma scan, and PuTTA analyses.

\subsection{Results and Discussion}

\subsection{Simulated Al Dissolution}

To determine the extent of loading for both the MST and CST, the concentrations of elements in the decontaminated solutions were measured, and these concentrations were compared to the starting concentrations in the simulants. These loading values were then used to determine the extent of desorption, by calculating the percentage of each sorbate that had leached from the sorbent at a given time. The concentrations of the sorbates in solution were measured at each sampling time. The concentration in the control solution was then subtracted from these values to determine the increase in sorbate concentration due to desorption from the sorbent.

Figures 1-4 provide plots of the percent sorbate leached from MST versus time under the simulated $\mathrm{Al}$ dissolution conditions for $\mathrm{Sr}, \mathrm{U}, \mathrm{Np}$, and $\mathrm{Pu}$, respectively. Plots of concentration versus time for each sorbate are provided in the Appendix. Under these conditions, all of the sorbates were found to desorb to varying degrees. In the case of ${ }^{85} \mathrm{Sr}$, the concentration in the control solution was below the quantifiable limit. Therefore, for calculating the percent of leaching, this concentration was assumed to be zero, which provides a high bias for the percent leached values for ${ }^{85} \mathrm{Sr}$. Thus, the percent leached values presented in Figure 1 are maximum values, and the actual values may be $10-15 \%$ lower. The ${ }^{85} \mathrm{Sr}$ reached maximum desorption at the first sampling time of six hours. At this time, a maximum of $50 \%$ of the ${ }^{85} \mathrm{Sr}$ had been leached from the MST. This value remained constant, within error, for the remaining time at $65{ }^{\circ} \mathrm{C}$. After cooling to $25^{\circ} \mathrm{C}$, some resorption was observed, as the concentration approached that of the control solution and the quantifiable limit.

Approximately $28 \%$ of the $\mathrm{U}$ had leached from the MST at the first sampling time of six hours. $\mathrm{U}$ continued to desorb over the length of the test, reaching a maximum desorption of approximately $49 \%$ after 4 weeks. When the temperature was reduced to $25{ }^{\circ} \mathrm{C}$, some resorption was observed, and the percent leached value dropped to $36 \%$ after two weeks at reduced temperature. (Note that these trends with temperature are substantiated by the data but the difference falls within the analytical uncertainty of the data for the most part.)

The Np concentration gradually increased over the first 3 weeks of the desorption period, reaching a maximum of approximately $31 \%$. The concentration at four weeks dropped slightly, but was within error of the 3 week value. A small amount of resorption was observed after decreasing the temperature to $25{ }^{\circ} \mathrm{C}$, with the percent leached value dropping to $19 \%$ (which does; however, fall within the experimental uncertainty).

$\mathrm{Pu}$ was found to desorb the least, reaching a maximum desorption of less than $3 \%$. After reducing the temperature to $25{ }^{\circ} \mathrm{C}$, some resorption occurred; reaching a percent leached level of only $\sim 1 \%$. 
SRNL-STI-2011-00340

Revision 0

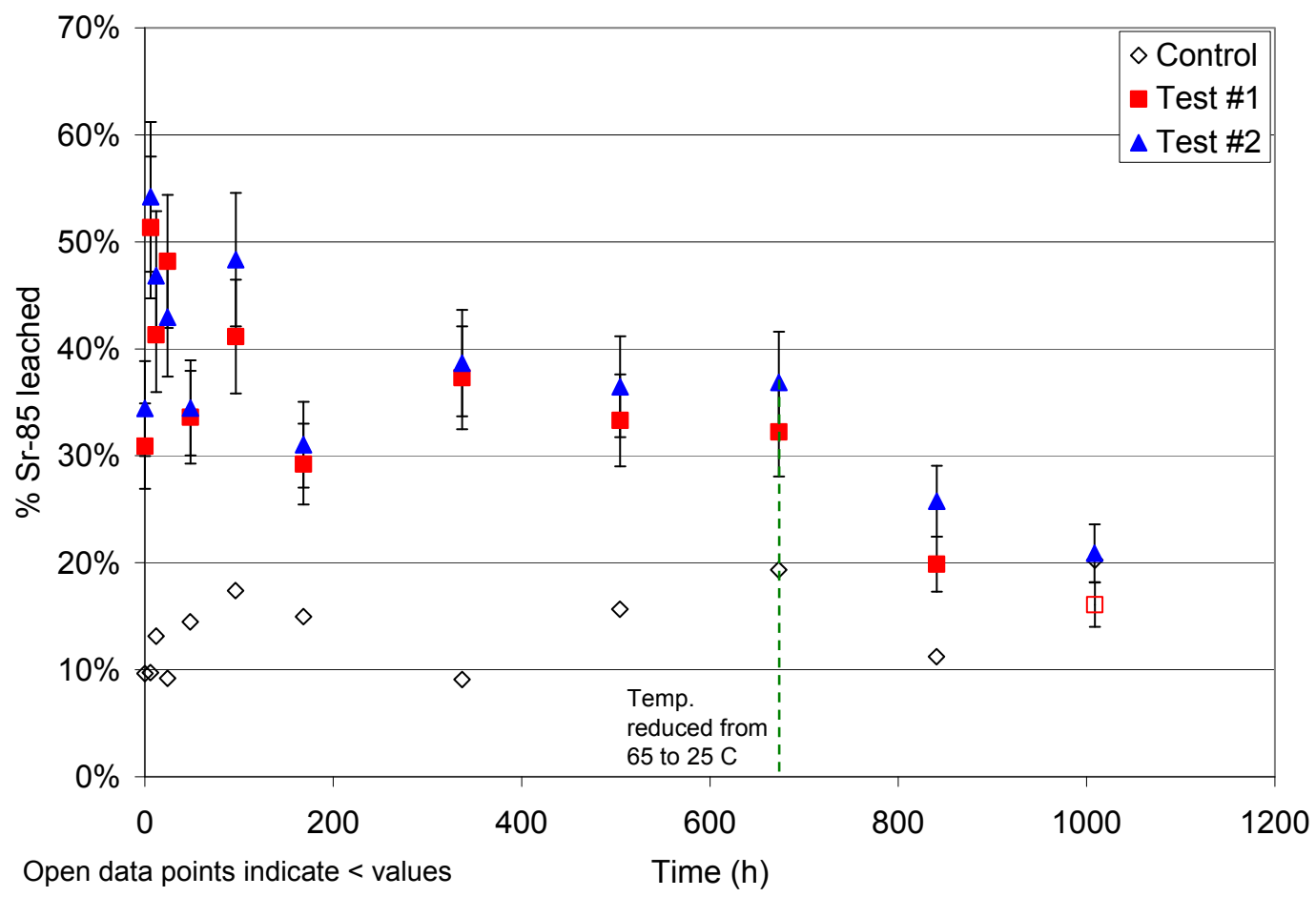

Figure 1. Percentage of ${ }^{85} \mathrm{Sr}$ leached from MST under simulated Al dissolution conditions (open data points indicate values that were below the quantifiable limit).

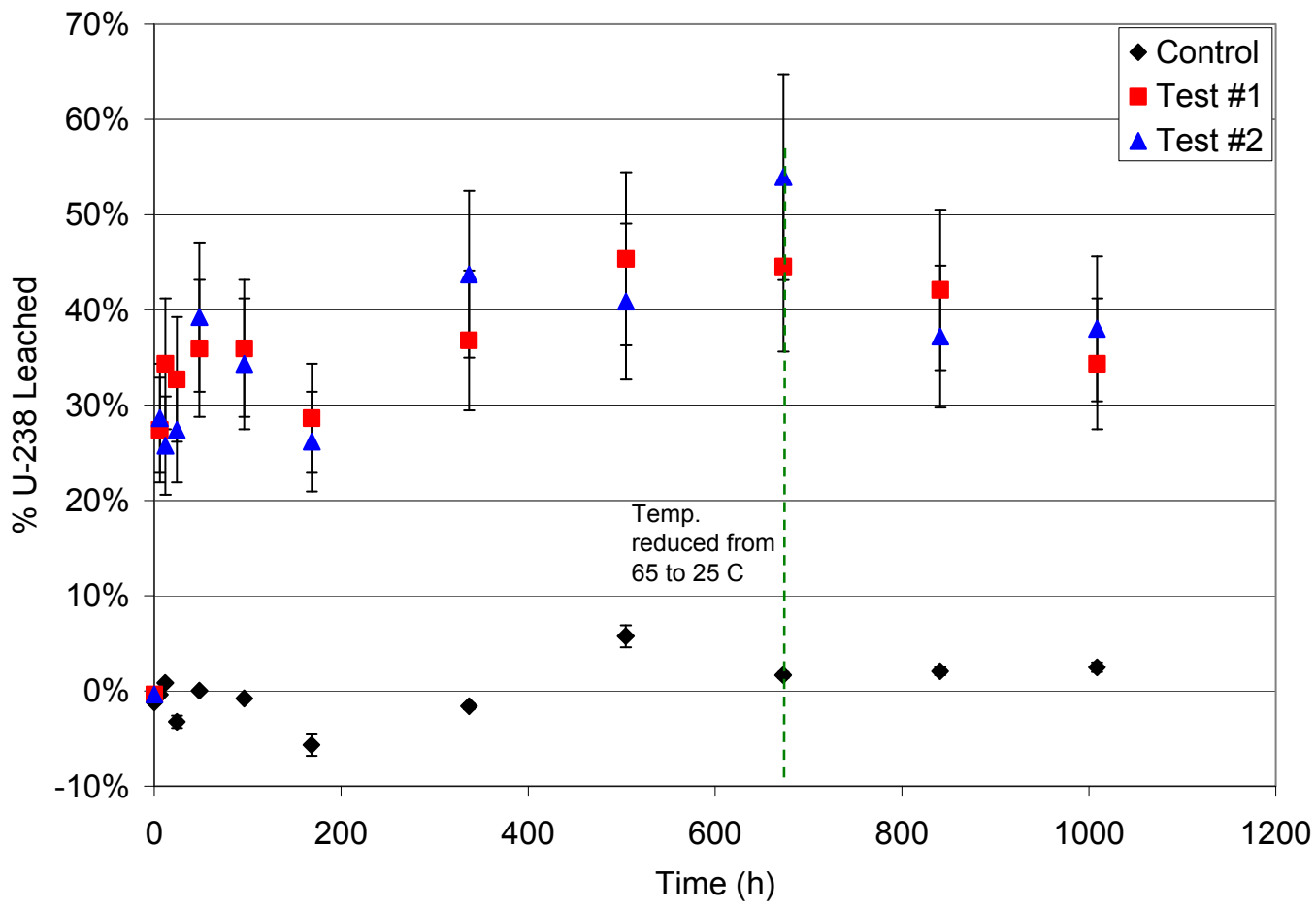

Figure 2. Percentage of ${ }^{238} \mathrm{U}$ leached from MST under simulated Al dissolution conditions. 
SRNL-STI-2011-00340

Revision 0

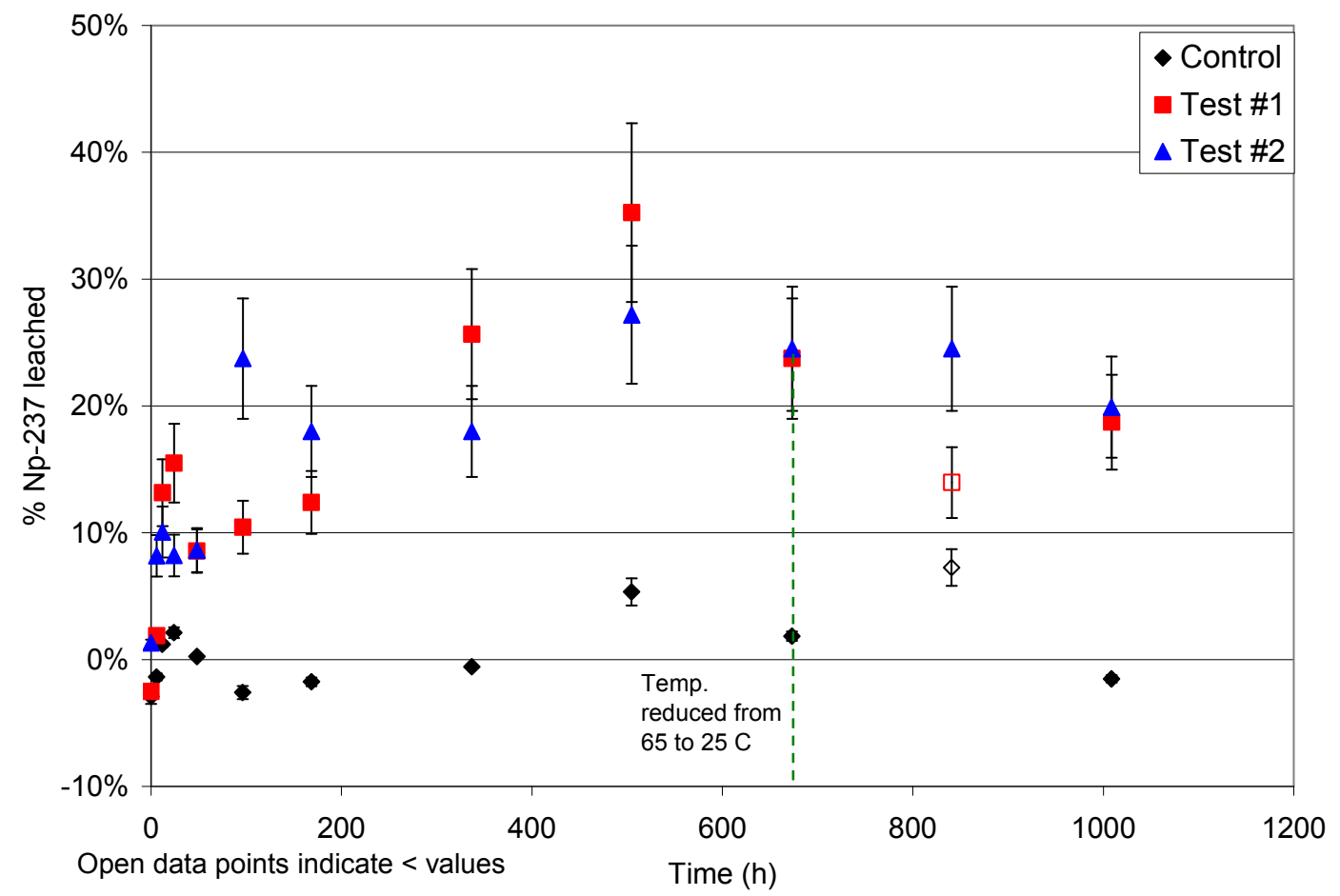

Figure 3. Percentage of ${ }^{237} \mathrm{~Np}$ leached from MST under simulated Al dissolution conditions.

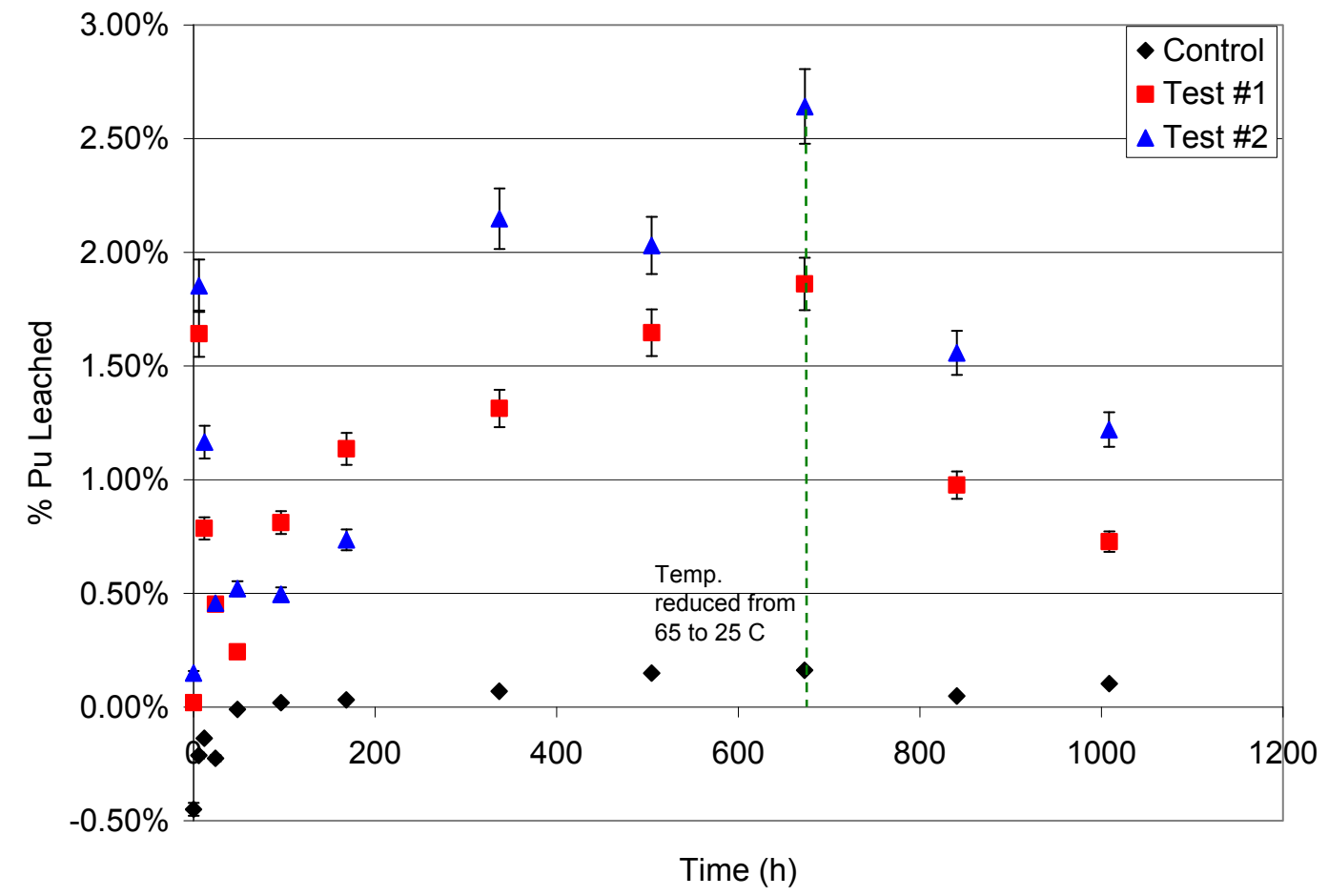

Figure 4. Percentage of Pu leached from MST under simulated Al dissolution conditions. 
The results from the Cs desorption experiments with CST under simulated Al dissolution conditions are shown in Figure 5. Cs was found to desorb rapidly, nearing the maximum desorption of $\sim 50 \%$ within 12 hours. After cooling to $25{ }^{\circ} \mathrm{C}$, approximately half of the Cs that had leached from the CST was resorbed. Previous work examined the Cs capacity of CST after storing at elevated temperature $\left(80{ }^{\circ} \mathrm{C}\right)$ in SRS average supernate simulant (without Cs). ${ }^{6}$ Samples of CST that had been stored in the simulant at $80^{\circ} \mathrm{C}$ for six months showed a decrease in Cs capacity of approximately 15\% compared to samples of CST that had been stored in the simulant at $23{ }^{\circ} \mathrm{C}$ for the same length of time. All loading tests to determine the Cs capacity were performed at $23^{\circ} \mathrm{C}$.

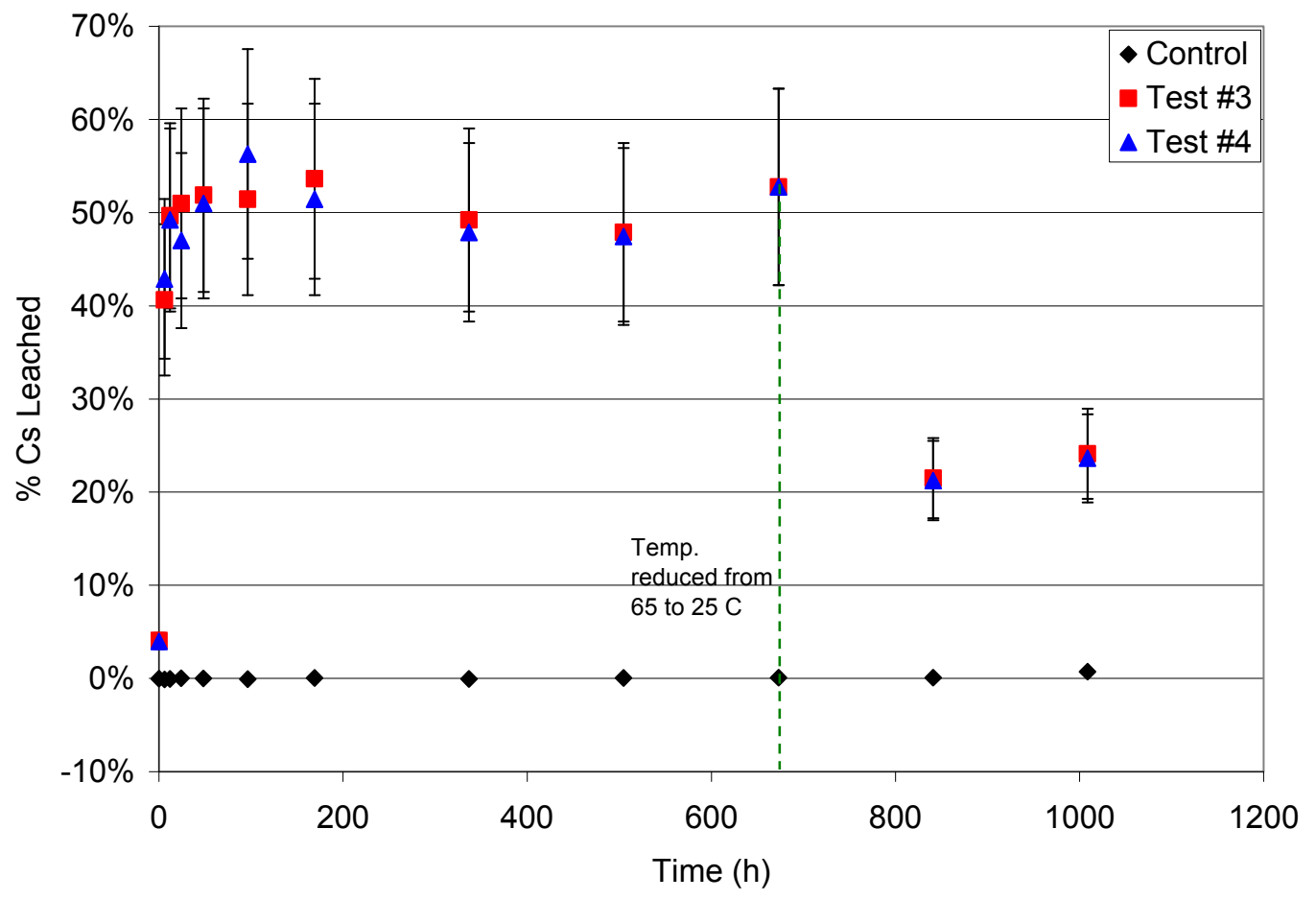

Figure 5. Percentage of Cs leached from CST under simulated Al dissolution conditions.

\subsection{Simulated Sludge Washing}

The simulated sludge washing was performed using DSS diluted to two different dilutions, representing intermediate and final stages of washing, i.e. $2 \mathrm{M}$ and $0.5 \mathrm{M} \mathrm{Na}$. These experiments were continued for a total of six weeks. During this time period, no evidence of desorption of any of the sorbates was observed for MST; however, additional sorption did occur under these conditions as evidenced by the decreasing solution concentrations. The ${ }^{85} \mathrm{Sr}$ concentrations for these diluted solutions were below the quantifiable limit. In both the $2 \mathrm{M}$ and $0.5 \mathrm{M}$ Na solutions, the $\mathrm{Pu}$ appeared to precipitate from solution as the $\mathrm{Pu}$ concentration in both control samples decreased significantly from the start of the test to the first sample at 24 hours of contact. The concentrations of the sorbates, $\mathrm{U}, \mathrm{Np}$, and $\mathrm{Pu}$, vs. time are shown in Figures 6-8. 
SRNL-STI-2011-00340

Revision 0

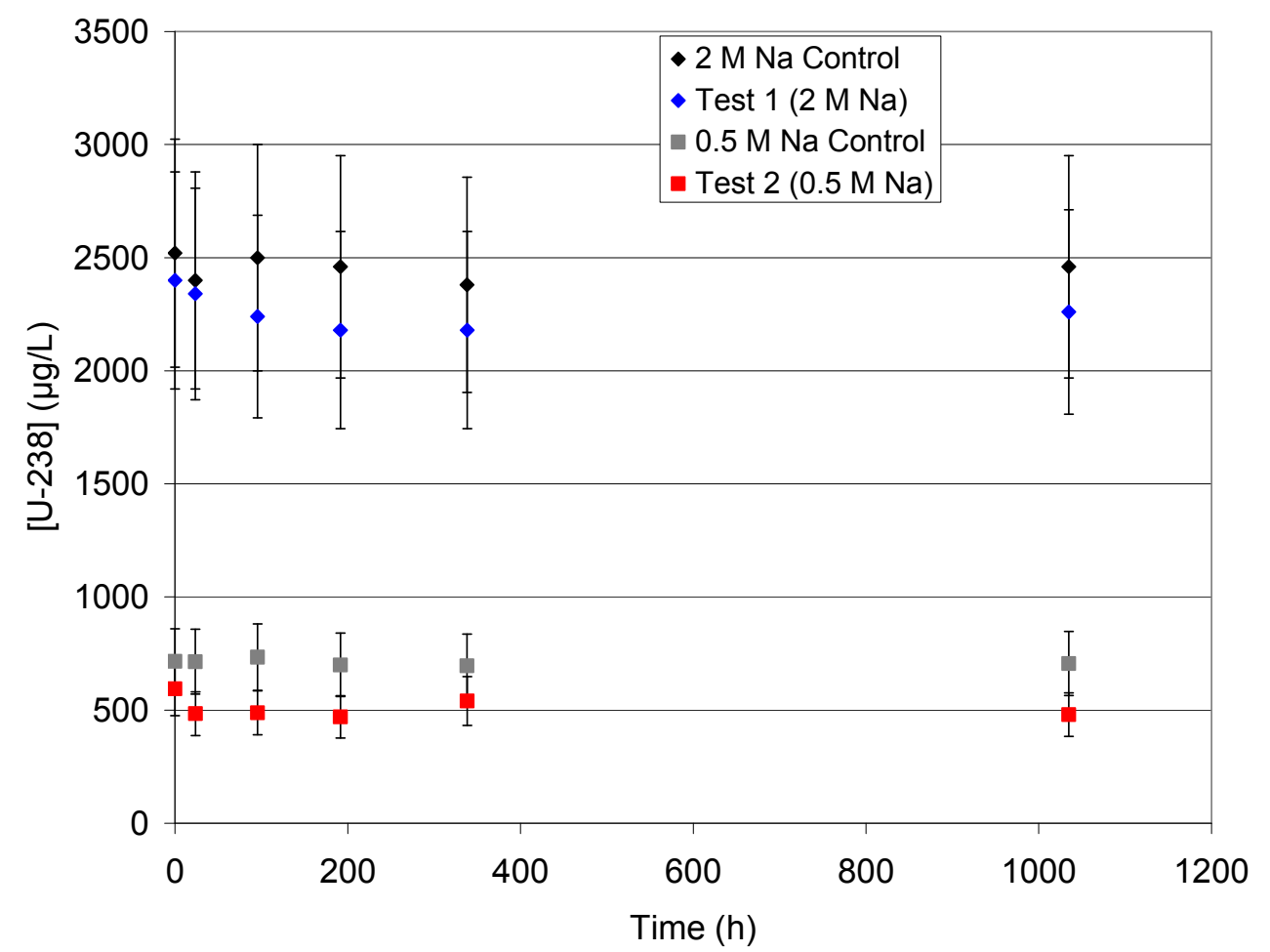

Figure 6. ${ }^{238} \mathrm{U}$ concentration vs. contact time under simulated sludge washing conditions.

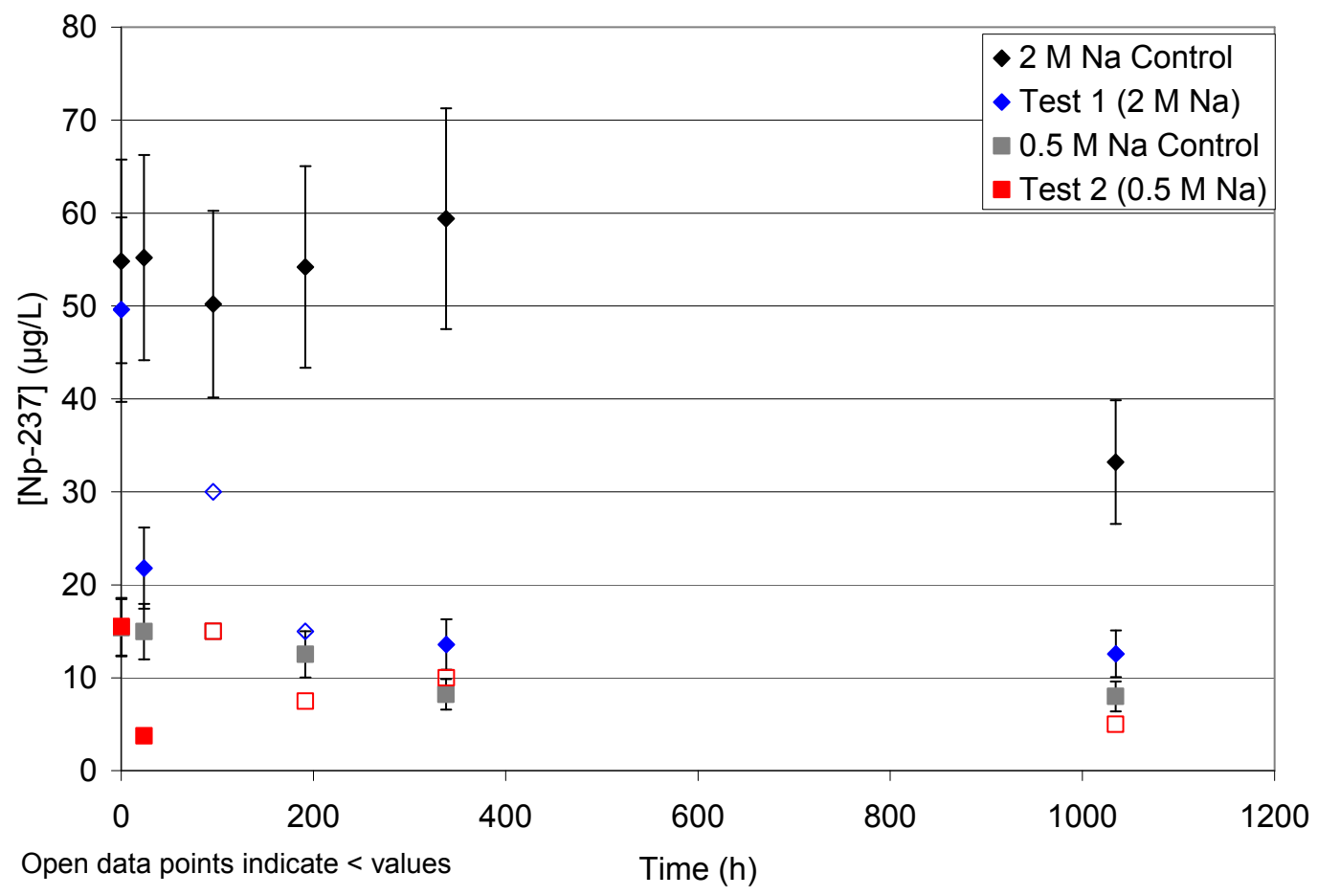

Figure 7. ${ }^{237} \mathrm{~Np}$ concentration vs. contact time under simulated sludge washing conditions (open data points indicate value that were below the quantifiable limit). 


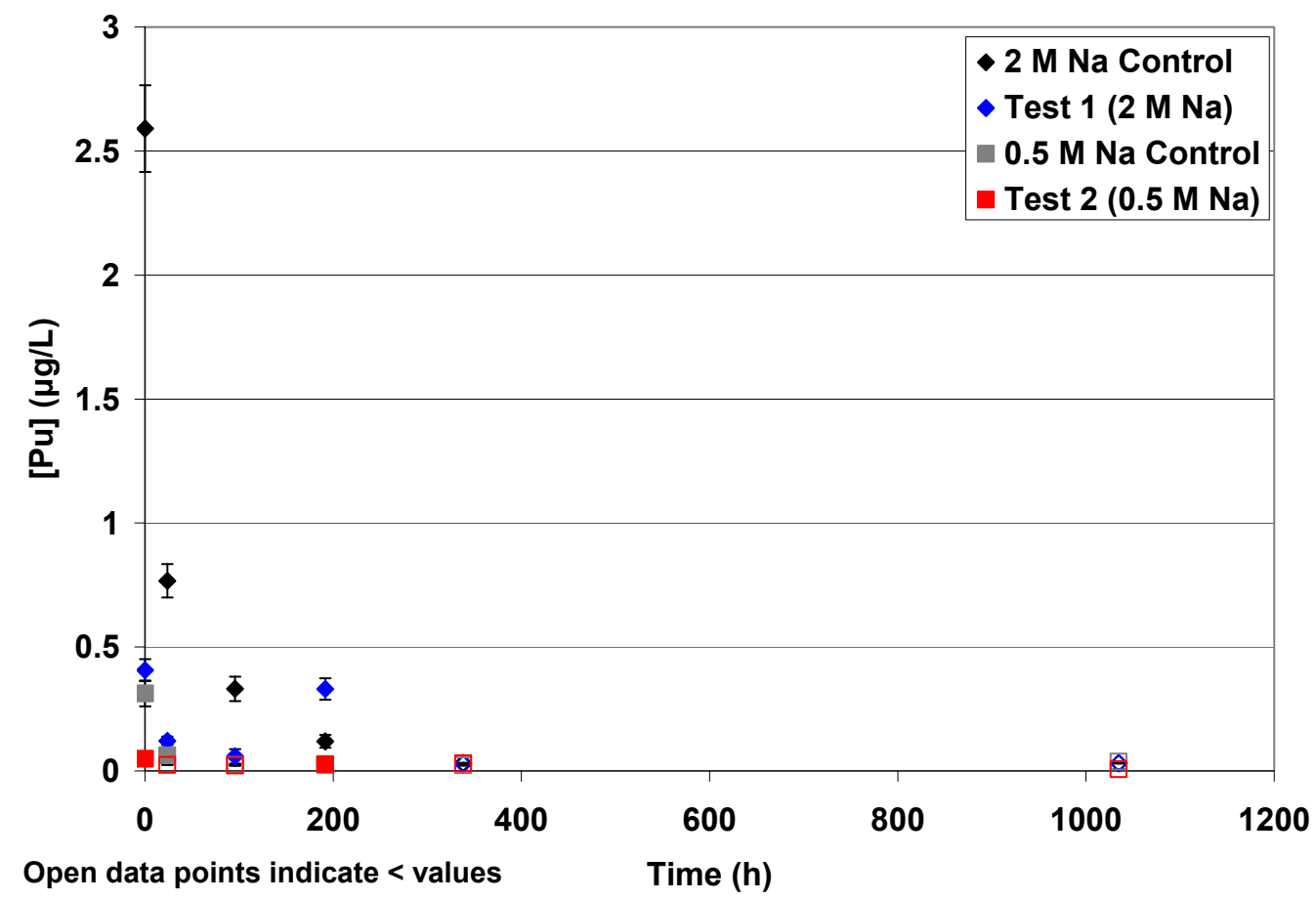

Figure 8. Pu concentration vs. contact time under simulated sludge washing conditions (open data points indicate value that were below the quantifiable limit).

The results from the Cs desorption experiments with CST under simulated sludge washing conditions are shown in Figures 9-10. A minimal amount of Cs was found to desorb in both solutions. In the $2 \mathrm{M}$ Na solution, approximately $2.5 \%$ of the Cs was found to desorb by the time the initial sample was taken (approx. 6 minutes). By 24 hours, this amount had increased slightly to just less than $4 \%$, and the concentration then remained constant for the remainder of the experiment. A similar release profile was seen in the more dilute, $0.5 \mathrm{M} \mathrm{Na}$, solution; however, the maximum desorption in this solution was less than $1 \%$. 


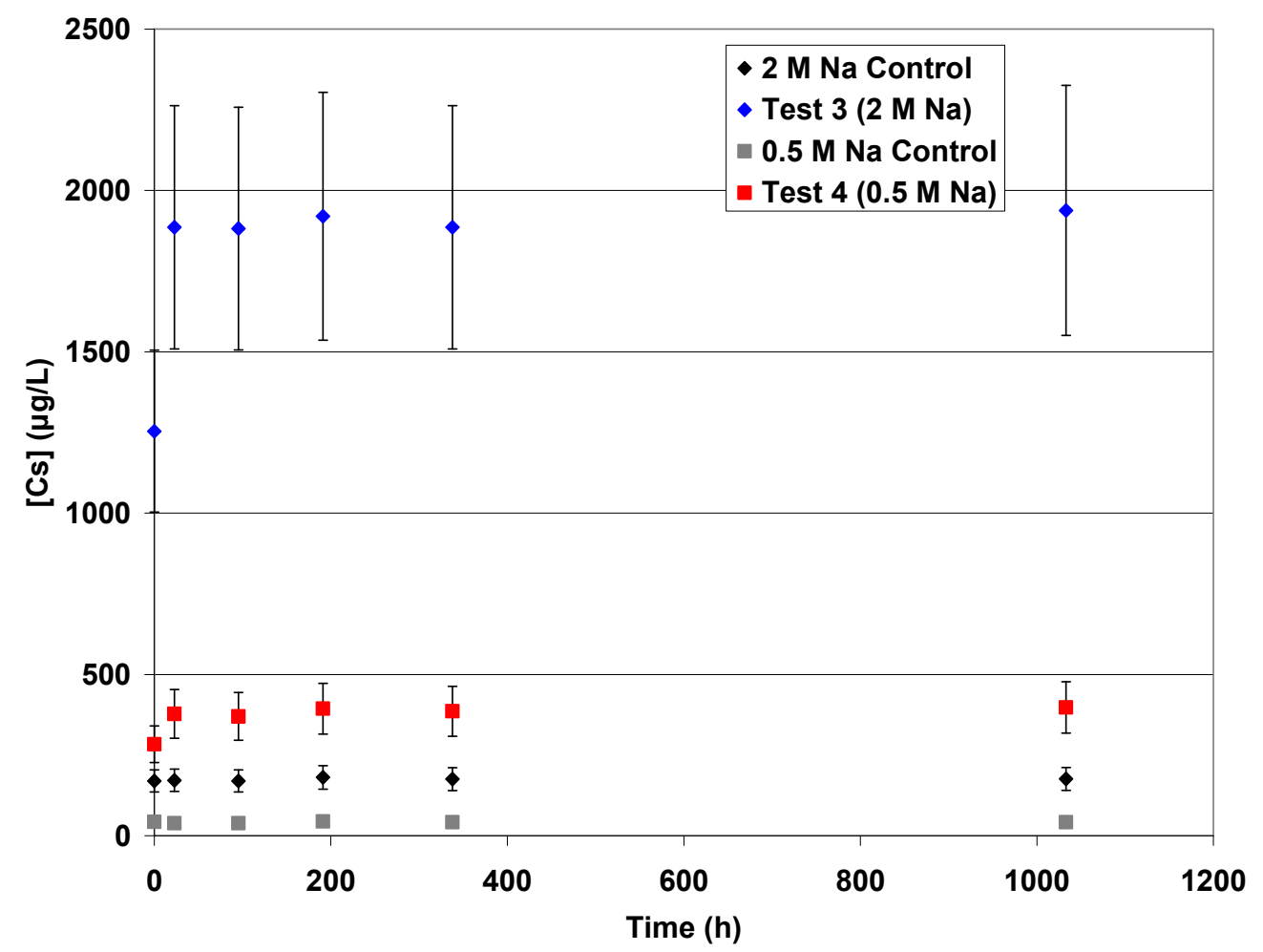

Figure 9. Cs concentration vs. contact time under simulated sludge washing conditions.

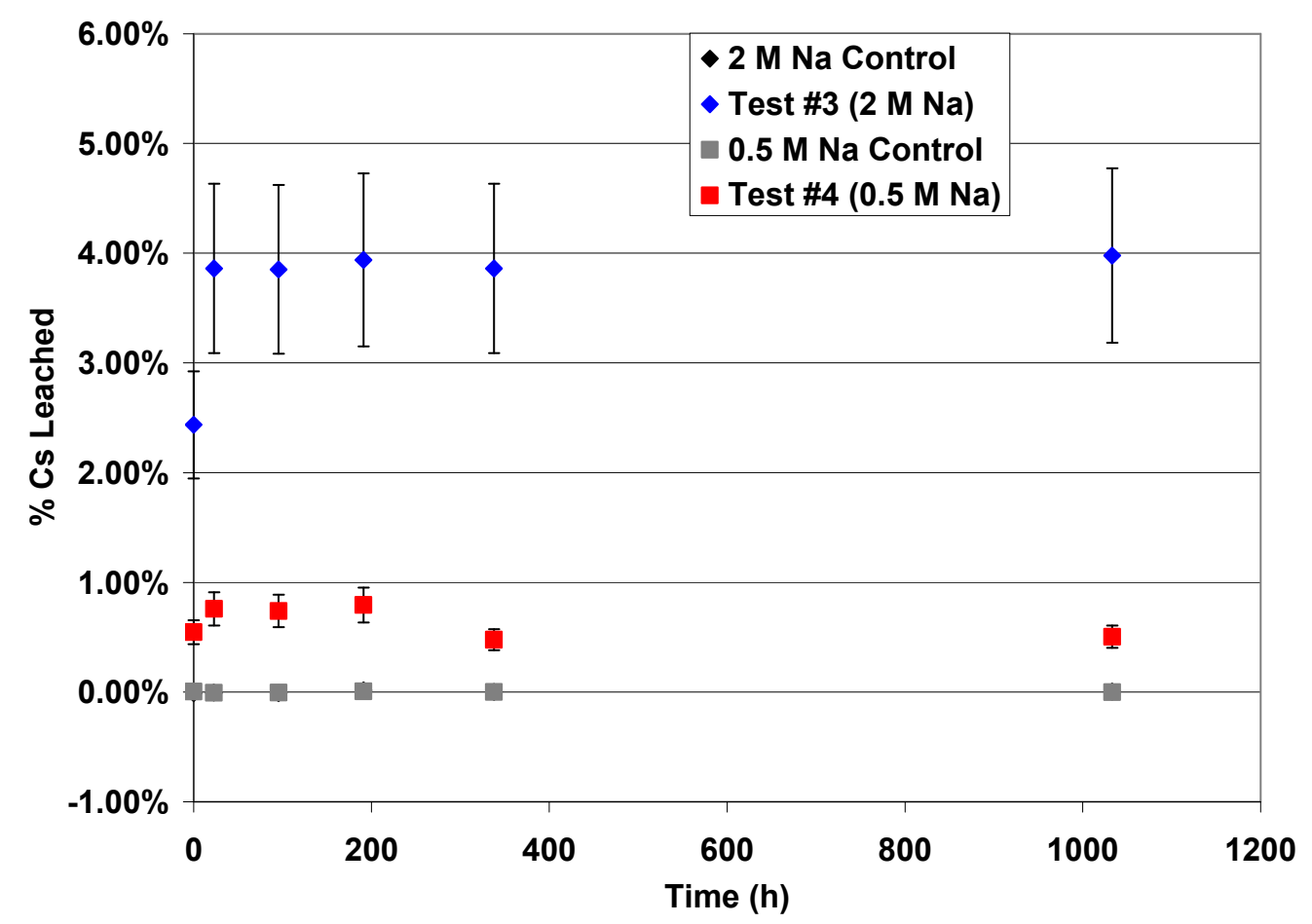

Figure 10. Percentage of Cs leached from CST under simulated sludge washing conditions (the $2 \mathrm{M}$ Na control data points are in the same positions as the $0.5 \mathrm{M}$ Na control data points, therefore they are hidden in this plot). 


\subsection{Desorption Under Changing Phase Ratio Conditions}

During the Sr and actinide sorption testing in support of SCIX, a leak occurred in the pump tubing, and approximately half of the solution was lost. ${ }^{1}$ After the leak occurred, the tubing was replaced and the tests were continued. After this leak occurred, the sorbate concentrations in solution began increasing as opposed to decreasing or remaining constant as expected. It was hypothesized that if mainly solution, not solids, was lost during the leak, the increased solid to liquid phase ratio could result in desorption of the sorbates back into solution.

To test this hypothesis, an experiment was performed using the material from the control tests in that earlier testing. These tests consisted of originally $200 \mathrm{~mL}$ of simulant in capped polyethylene bottles with $0.4 \mathrm{~g} / \mathrm{L}$ and $0.2 \mathrm{~g} / \mathrm{L}$ of MST and mMST, respectively. When these bottles were sampled, the contents were mixed vigorously by shaking to ensure the solids were homogeneously suspended. Therefore, the solids concentrations are expected to be very close to the same as they were at the start of the experiments. For the current desorption experiments, the MST and mMST concentrations of these samples were increased by a factor of approximately 2 based on the volume of supernate removed from each bottle, resulting in final concentrations being $0.77 \mathrm{~g} / \mathrm{L}$ and $0.35 \mathrm{~g} / \mathrm{L}$ for MST and mMST, respectively. Samples were then removed at times of 2,4 , and 6 weeks.

The ${ }^{85} \mathrm{Sr}$ levels in all samples were below the quantifiable limit, along with the majority of the stable $\mathrm{Sr}$ concentrations from the ICP-MS data. Therefore, no conclusions could be drawn regarding the desorption of $\mathrm{Sr}$ under these conditions. The U concentrations in both the MST and mMST experiments appeared to remain fairly constant over the 6 week period, with no evidence of desorption or additional sorption (Fig. 11).

In the case of $\mathrm{Np}, \mathrm{mMST}$ appeared to continue to adsorb additional $\mathrm{Np}$, as the concentration in solution decreased over the test period (Fig. 12). The 2 and 6-week samples for the MST experiment fell below the quantifiable limit for $\mathrm{Np}$; however, the concentration at 4-weeks is slightly higher than the initial concentration, indicating possible desorption (Fig. 12). However, when the analytical uncertainty is taken into account, these two values are not statistically different. The Pu data indicate two different results for MST and mMST. The mMST appeared to continue to adsorb additional $\mathrm{Pu}$ over the six week period, whereas MST appeared to desorb $\mathrm{Pu}$ initially, and then resorb some of the leached Pu (Fig. 13). The Pu concentration in the MST experiment increased by a factor of approximately 1.8 during the first two weeks, and then began to decrease, reaching a final concentration slightly higher than the starting concentration. Results from this test do not confirm the hypothesis that a change in sorbent concentration leads to desorption. 
SRNL-STI-2011-00340

Revision 0

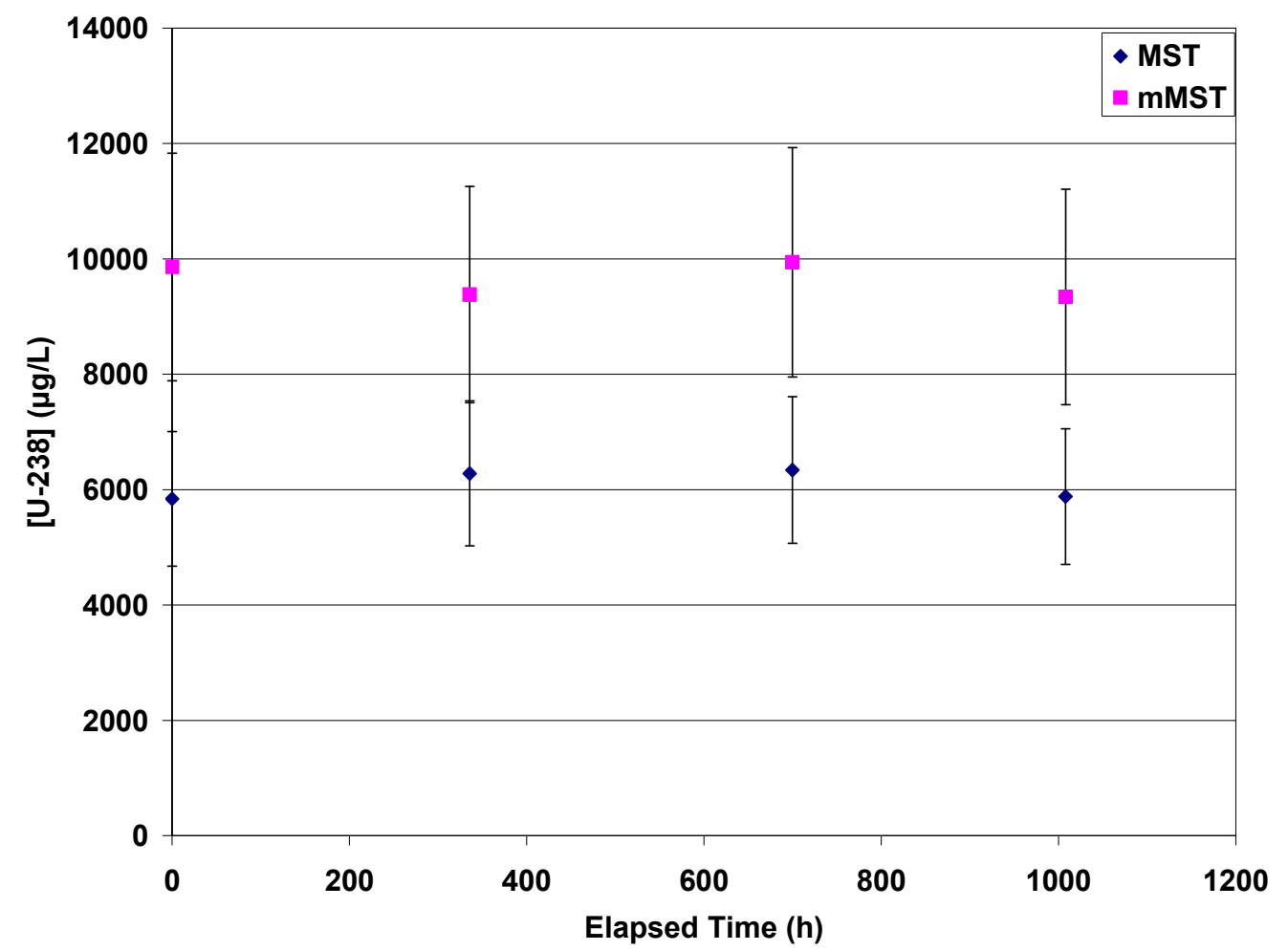

Figure 11. ${ }^{238} \mathrm{U}$ concentration vs. time after increasing the solid to liquid phase ratio.

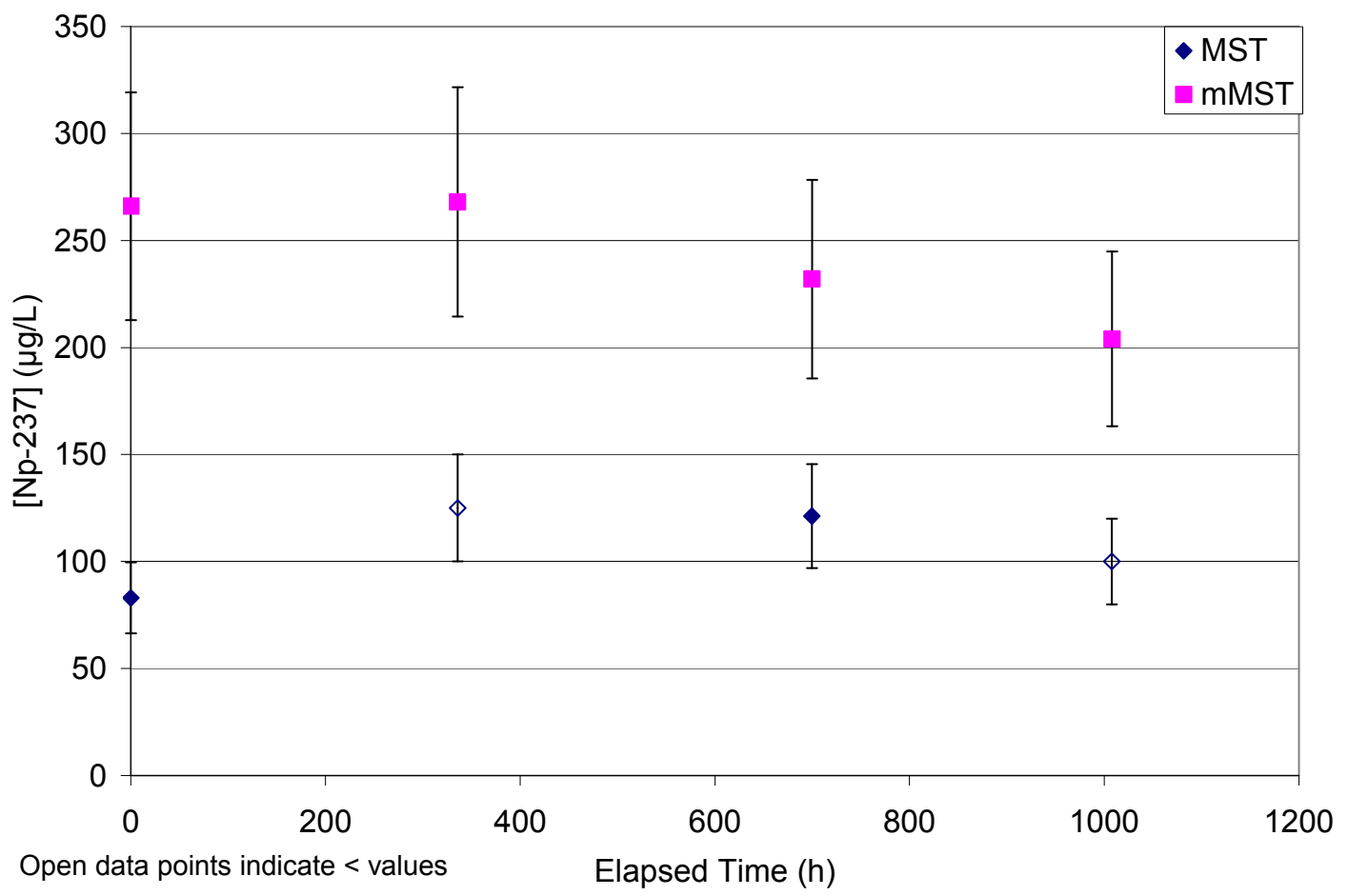

Figure 12. ${ }^{237} \mathrm{~Np}$ concentration vs. time after increasing the solid to liquid phase ratio. 
SRNL-STI-2011-00340

Revision 0

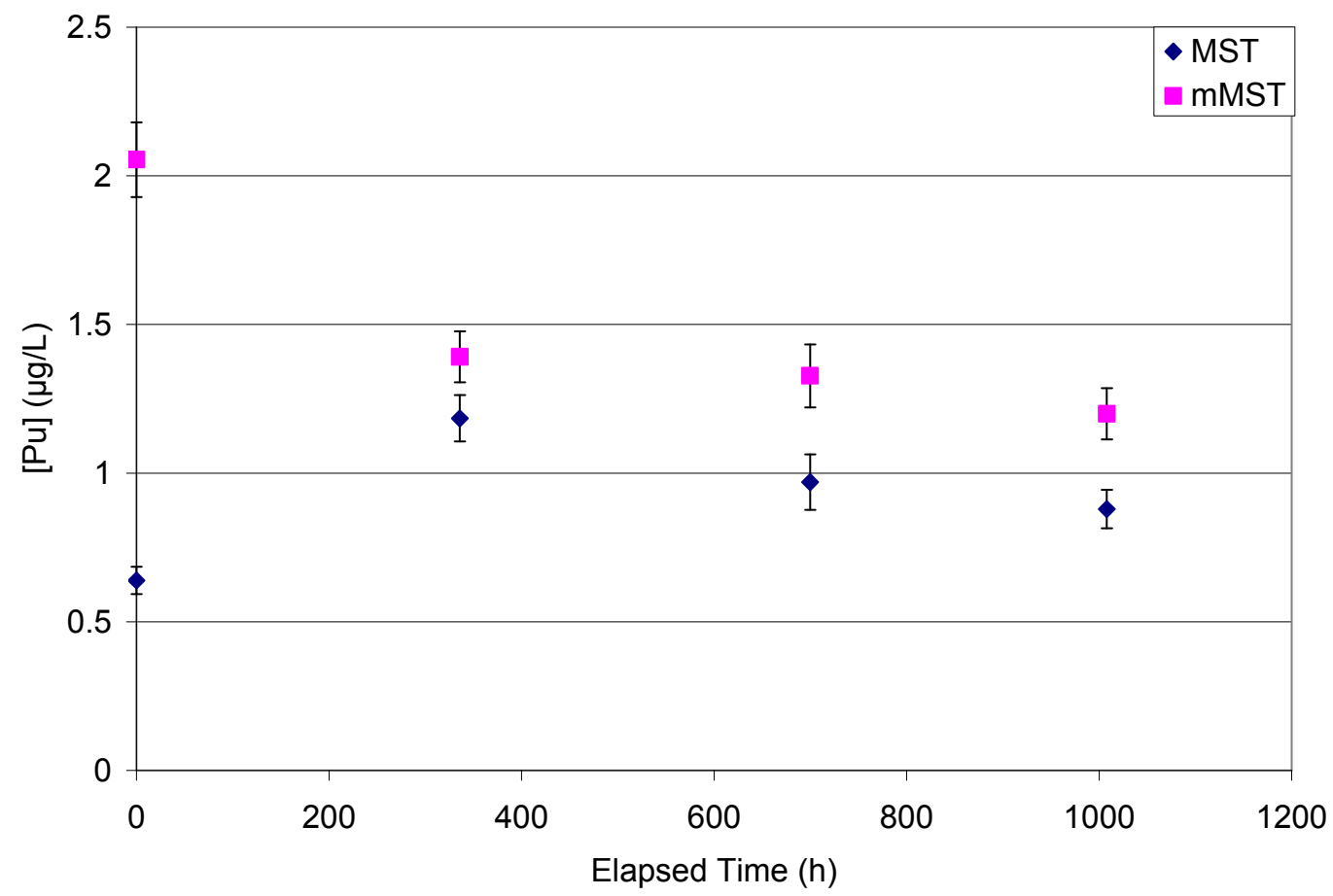

Figure 13. Pu concentration vs. time after increasing the solid to liquid phase ratio.

\subsection{Conclusions}

Under the simulated Al dissolution conditions, desorption of all sorbates from both MST and CST was observed, but to varying degrees. Desorption from MST ranged from $<3 \%(\mathrm{Pu})$ to about $50 \%$ ( $\mathrm{Sr}$ and $\mathrm{U}$ ). The percent leached values reported for ${ }^{85} \mathrm{Sr}$ represent maximum values, since the ${ }^{85} \mathrm{Sr}$ concentration in the control solution was below the quantifiable limit. Cs was found to desorb rapidly from CST, nearing the maximum desorption of about $50 \%$ after only 12 hours. After the 4-week Al dissolution cycle, the temperature was reduced from $65{ }^{\circ} \mathrm{C}$ to $25{ }^{\circ} \mathrm{C}$ to determine if the leaching was due to the chemical change of the solution (i.e. increased hydroxide concentration) or the increased temperature. After reducing the temperature to $25^{\circ} \mathrm{C}$, some resorption of all sorbates was observed.

Under the simulated sludge washing conditions with MST, no desorption of any sorbates was observed over the 6 week test period; however, additional sorption of some elements was observed. For CST, a minimal amount of Cs was found to desorb during the first day of testing, and the concentration then remained constant for the remaining test period. The amount of $\mathrm{Cs}$ that desorbed corresponded to about $4 \%$ in the $2 \mathrm{M} \mathrm{Na}$ solution, and $<1 \%$ in the $0.5 \mathrm{M} \mathrm{Na}$ solution.

The final set of experiments was designed to determine if changing the solid to liquid phase ratio would result in desorption of sorbates from the MST or mMST. Based on the observed sorbate concentrations, we conclude that changing the solid to liquid phase ratio after an extended sorption period was not responsible for the observed desorption in the earlier experiment. 


\subsection{References}

1. K. M. L. Taylor-Pashow, D. T. Hobbs, and M. R. Poirier, "Strontium and Actinide Sorption by MST and mMST Under Conditions Relevant to the Small Column Ion-Exchange (SCIX) Process", SRNL-STI-2011-00215, Rev. 0, April 2011.

2. T. H. Huff, "SRNL Testing to Support Modular Salt Processing Project - Resin Loading Studies", HLE-TTR-2010-001, Rev. 0, March 2010.

3. K. M. L. Taylor-Pashow, M. R. Poirier, Z. Qureshi, F. F. Fondeur, T. B. Peters, D. T. Hobbs, and S. D. Fink, "Task Technical and Quality Assurance Plan for Testing to Support Modular Salt Processing Project - Monosodium Titanate Studies", SRNL-RP-2010-00686, Rev. 2, May 2011.

4. J. A. Pike and J. M. Gillam, "Flowsheet for Aluminum Removal from Sludge Batch 6" SRNL-STI-2008-00389, Rev. 0, December 2008.

5. J. M. Pareiz, B. R. Pickenheim, C. J. Bannochie, A. L. Billings, N. E. Bibler, D. R. Click, "Sludge Washing and Demonstration of the DWPF Flowsheet in the SRNL Shielded Cells for Sludge Batch 6 Qualification", SRNL-STI-2010-00353, Rev. 0, October 2010.

6. P. A. Taylor and C. H. Mattus, "Thermal and Chemical Stability of Baseline and Improved Crystalline Silicotitanate”, ORNL/TM-2001/165, December 2001. 
Appendix A. Supplemental Figures 


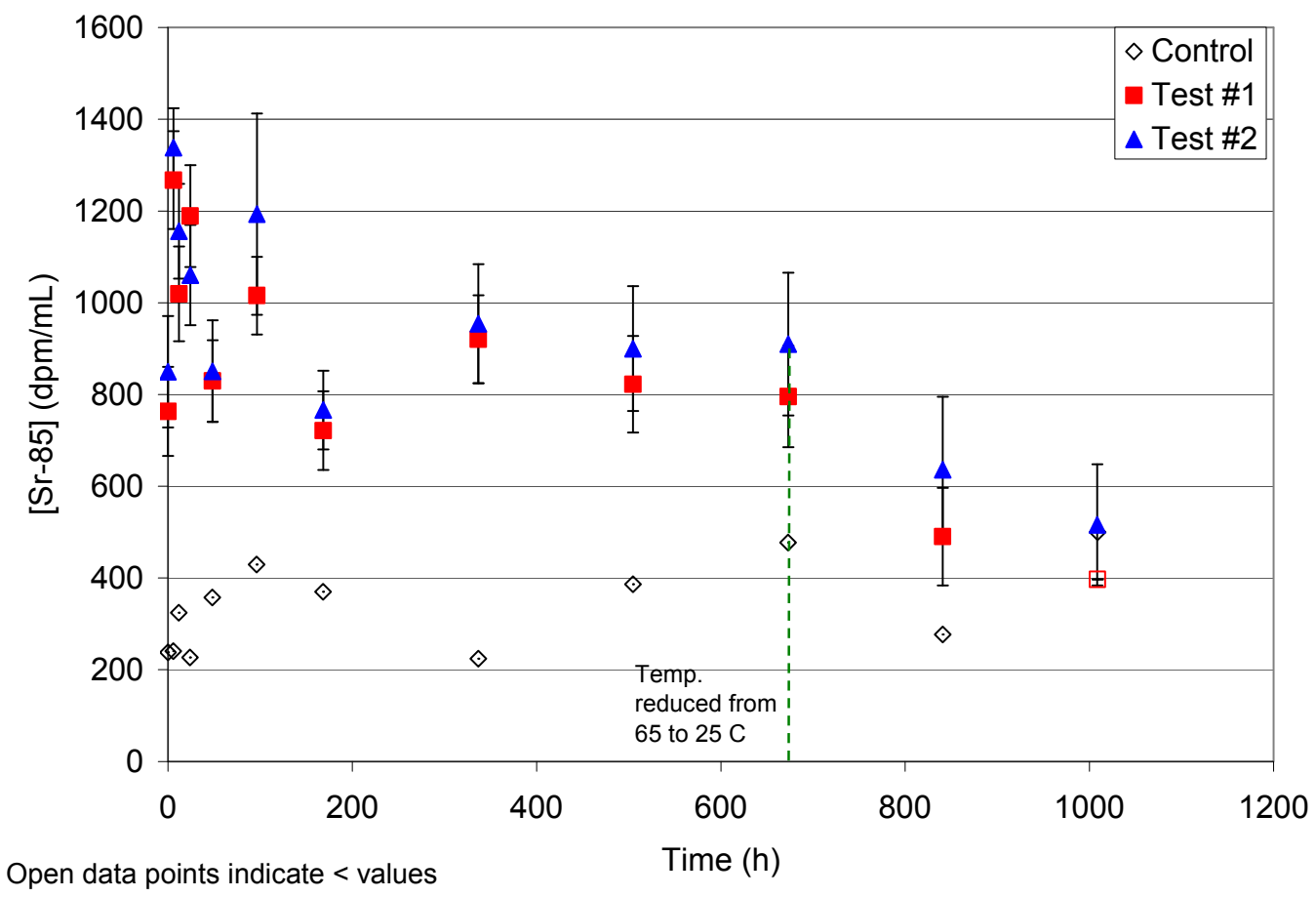

Figure 14. Activity of ${ }^{85} \mathrm{Sr}$ leached from MST vs. time under simulated Al dissolution conditions (open data points indicate values that were below the quantifiable limit).

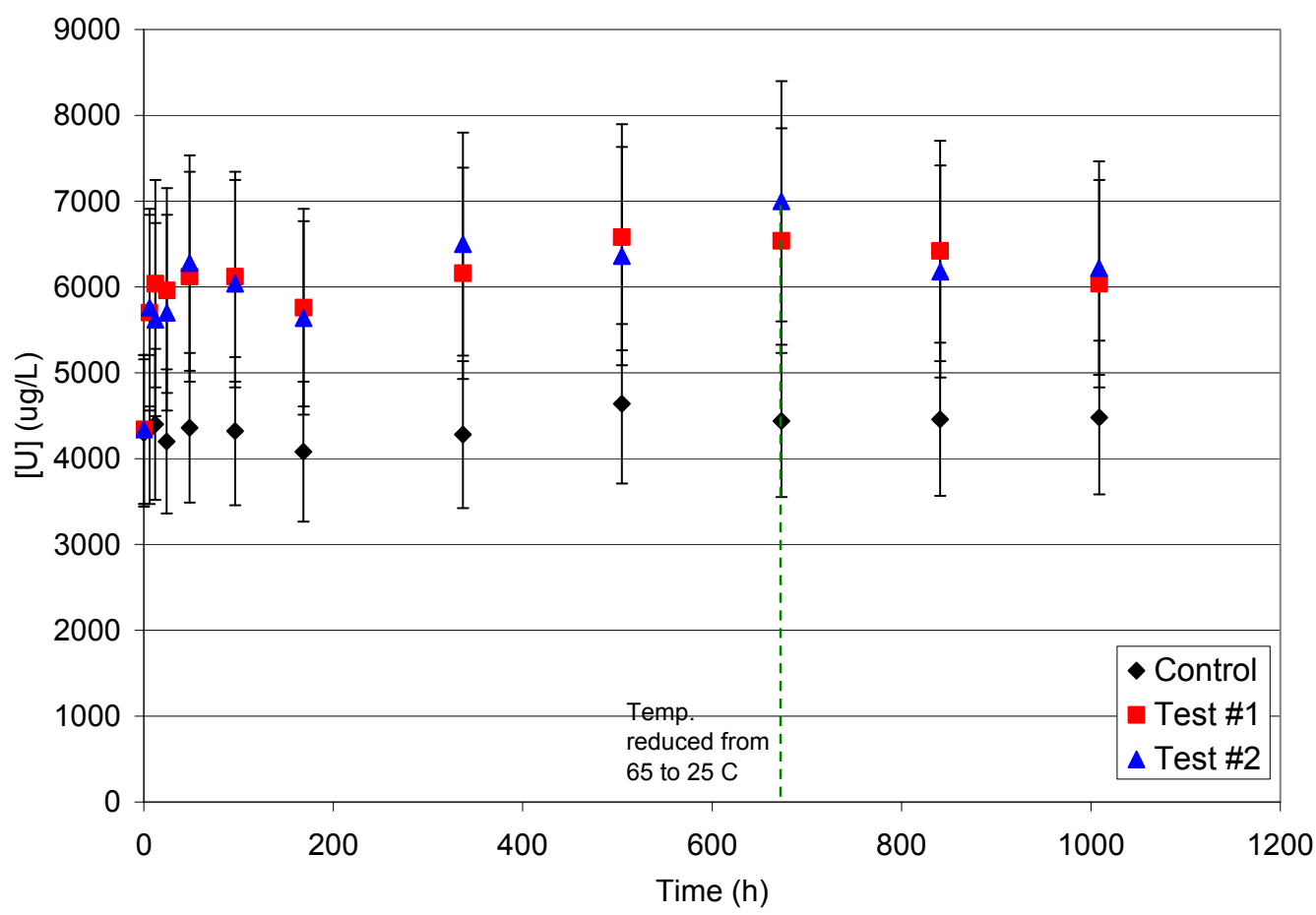

Figure 15. Concentration of $U$ leached from MST vs. time under simulated Al dissolution conditions. 


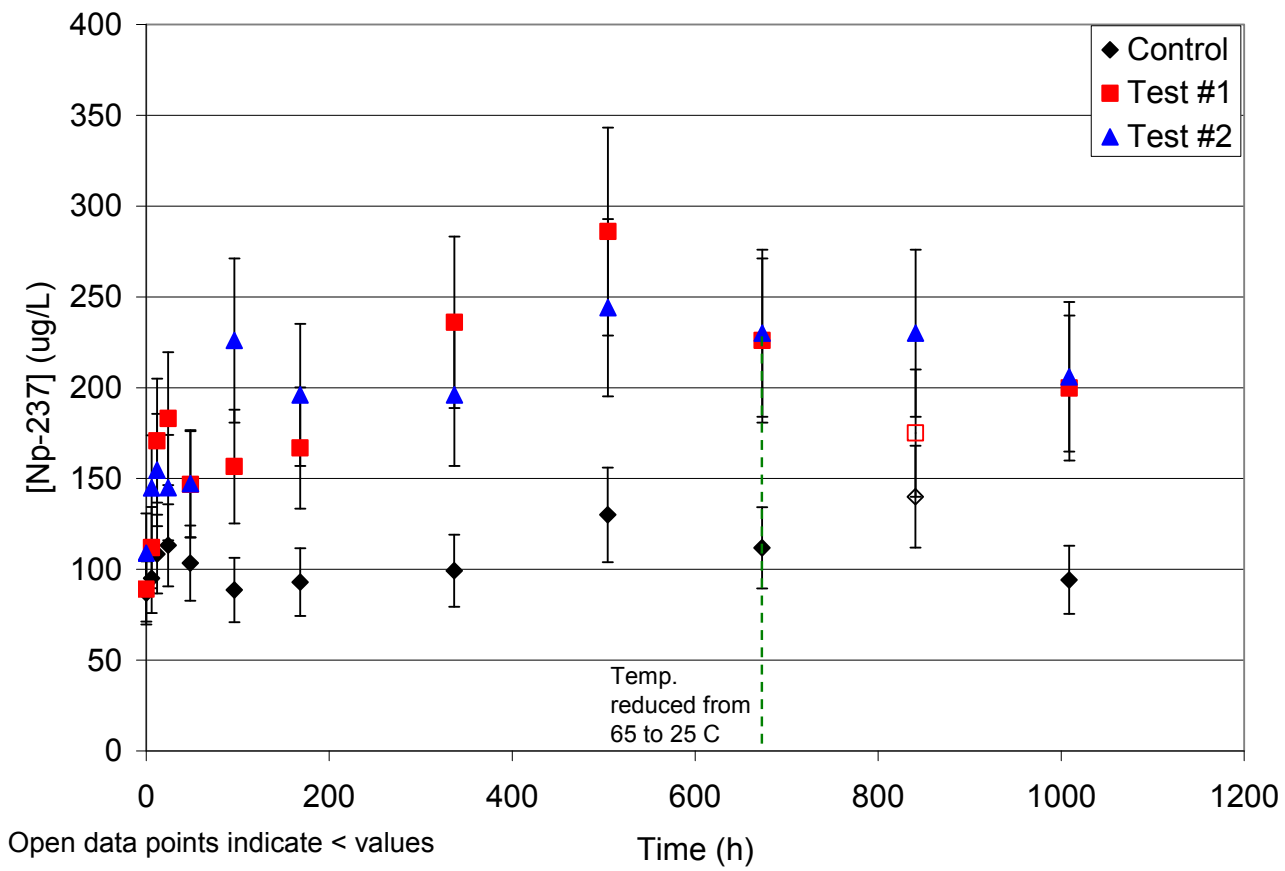

Figure 16. Concentration of ${ }^{237} \mathrm{~Np}$ leached from MST vs. time under simulated Al dissolution conditions (open data points indicate values that were below the quantifiable limit).

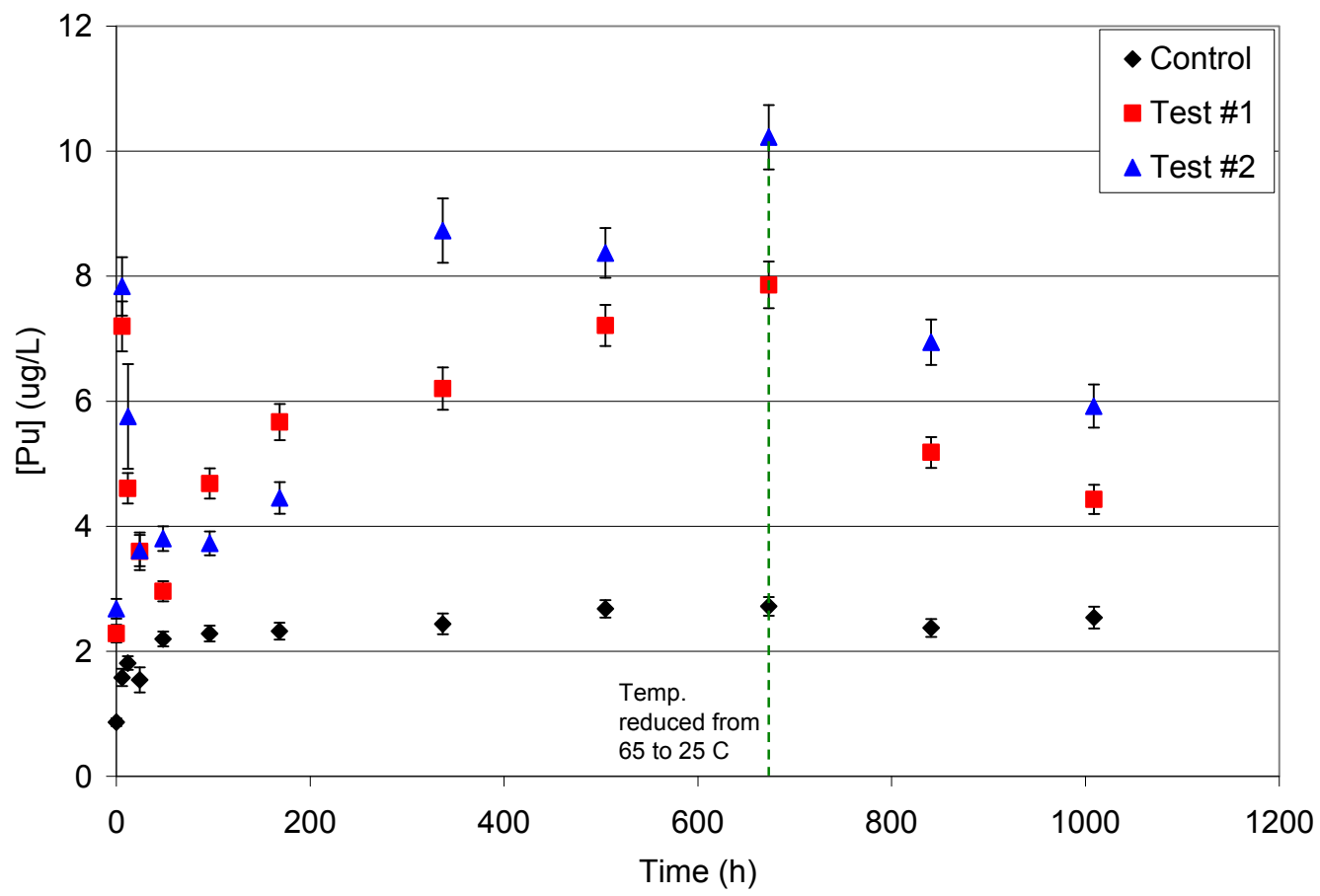

Figure 17. Concentration of Pu leached from MST vs. time under simulated Al dissolution conditions. 
SRNL-STI-2011-00340

Revision 0

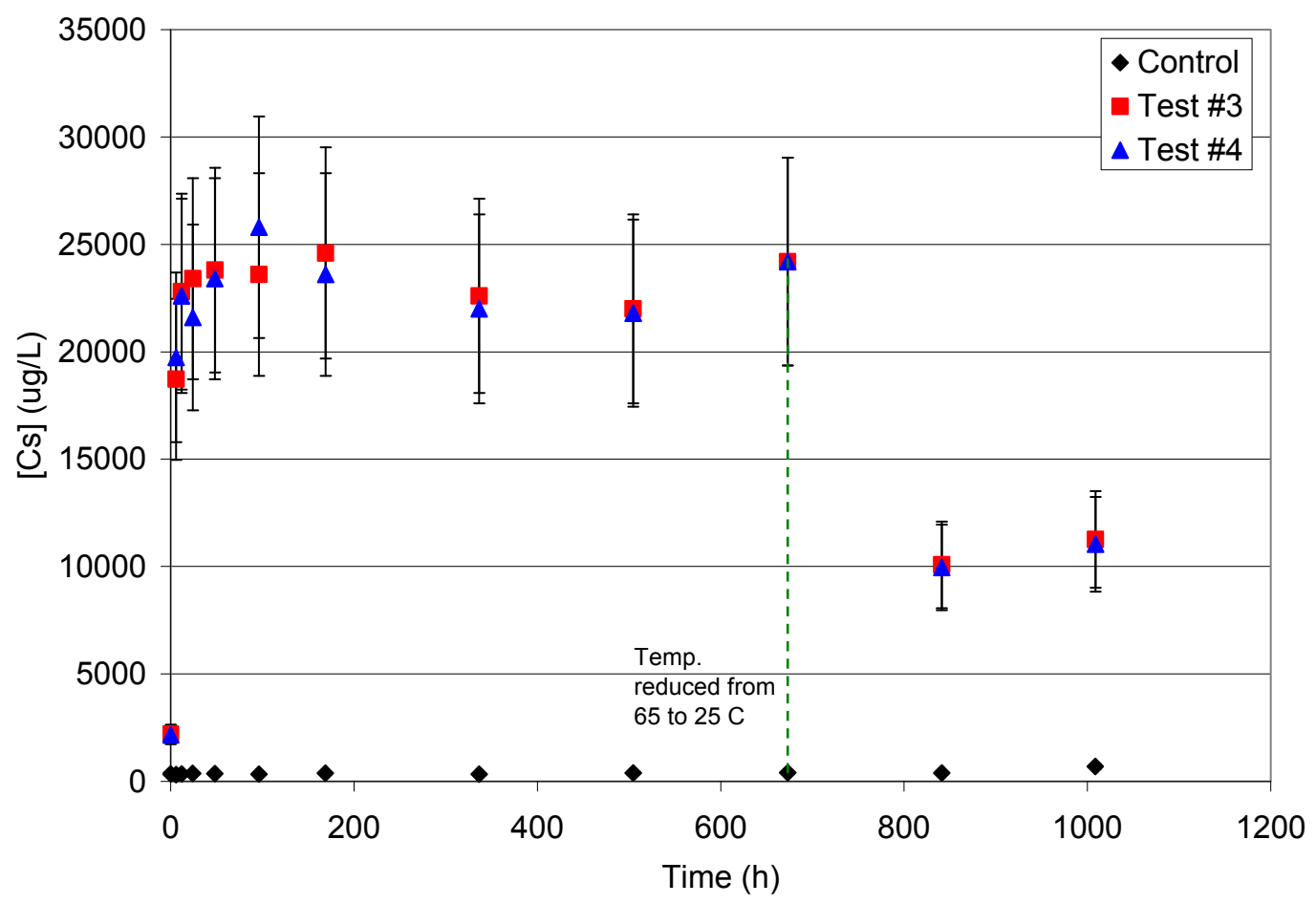

Figure 18. Concentration of Cs leached from CST vs. time under simulated Al dissolution conditions. 


\section{Distribution:}
A. B. Barnes, 999-W
D. A. Crowley, 773-43A
S. D. Fink, 773-A
B. J. Giddings, 786-5A
C. C. Herman, 999-W
S. L. Marra, 773-A
A. M. Murray, 773-A
F. M. Pennebaker, 773-42A
W. R. Wilmarth, 773-A
K. M. L. Taylor-Pashow, 773-A
D. T. Hobbs, 773-A
T. B. Peters, 773-42A
F. F. Fondeur, 773-A
P. R. Jackson, DOE-SR, 703-46A
K. H. Subramanian, 766-H
M. A. Rios-Armstrong, 773-66A
T. H. Huff, 773-66A
R. E. Edwards, 773-67A
M. W. Geeting, 241-152H
K. L. Lang, 704-27S
B. A. Oard, 704-61H 